\title{
Relationship between tectonism and desertification inferred from provenance and lithofacies changes in the Cenozoic terrestrial sequence of the southwestern Tarim Basin
}

\author{
Aki Sakuma ${ }^{1 *}\left(\mathbb{D}\right.$, Ryuji Tada ${ }^{2,3}$, Tomohiro Yoshida ${ }^{1}$, Hitoshi Hasegawa ${ }^{4}$, Naomi Sugiura ${ }^{1}$, Akinori Karasuda ${ }^{1}$, \\ Ke Wang ${ }^{3,5}$ and Hongbo Zheng ${ }^{3,6}$
}

\begin{abstract}
The modern-day Tarim Basin is covered almost entirely by the Taklimakan sand desert and is one of the most arid regions in the world. Unraveling the aridification history of the desert is important for understanding global climate changes during the Cenozoic, yet the timing and mechanisms driving its formation remain controversial. One of the leading hypotheses is that the uplift of the Pamir, located to the west of the Tarim Basin, blocked the intrusion of moist air and induced the aridification in the Tarim Basin. In this study, we explore the linkage between the uplift of the Pamir and the desertification in the Tarim Basin from the late Eocene to the middle Miocene in the Aertashi section, which is located at the southwestern edge of the Tarim Basin and offers the longest sedimentary record with a reliable age model. Provenance changes in fluvial deposits along the Aertashi section were examined using electron spin resonance (ESR) signal intensity and crystallinity index (CI) of quartz in the sand fraction of fluvial sandstones and clast counting based on the identification of clast types by thin section observation to identify timings of tectonic events in the Pamir, from which clastic materials were supplied to the Aertashi section by rivers. Our results suggest that major provenance changes in the drainage of the paleo-Yarkand river delivering clasts to the Aertashi section occurred at ca. 27, 20, and $15 \mathrm{Ma}$. These timings are mostly consistent with those observed in previous provenance studies in the Aertashi section and probably reflect tectonic events in the Pamir. On the other hand, according to the previous studies, the first occurrence of sand dune deposits indicates that the Tarim Basin was relatively arid after ca. $34 \mathrm{Ma}$. Hence, our result does not support the hypothesis that the initial aridification in the Tarim Basin was triggered by the uplift of the Pamir and the resultant blocking of moisture supply from the Paratethys Sea, although the subsequent intensification of tectonic events at ca. $27 \mathrm{Ma}$ in the Pamir might have caused aridification indicated by the initiation of loess deposition.
\end{abstract}

Keywords: Tarim Basin, Pamir, ESR signal intensity, Desertification, Aertashi section, Provenance

\footnotetext{
* Correspondence: a.sakuma@eps.s.u-tokyo.ac.jp

${ }^{1}$ Department of Earth and Planetary Science, Graduate School of Science,

The University of Tokyo, 7-3-1 Hongo, Bunkyo-ku, Tokyo 113-0033, Japan

Full list of author information is available at the end of the article
}

(c) The Author(s). 2021 Open Access This article is licensed under a Creative Commons Attribution 4.0 International License, which permits use, sharing, adaptation, distribution and reproduction in any medium or format, as long as you give appropriate credit to the original author(s) and the source, provide a link to the Creative Commons licence, and indicate if changes were made. The images or other third party material in this article are included in the article's Creative Commons licence, unless indicated otherwise in a credit line to the material. If material is not included in the article's Creative Commons licence and your intended use is not permitted by statutory regulation or exceeds the permitted use, you will need to obtain permission directly from the copyright holder. To view a copy of this licence, visit http://creativecommons.org/licenses/by/4.0/. 


\section{Introduction}

The Tarim Basin, located on the north side of the Tibetan Plateau (Fig. 1), is one of the most arid places in the world (National Center for Atmospheric Research Staff, 2018). The majority of the basin is covered by sand dunes that characterize the Taklimakan desert. The wadi and dry lakes located around the Taklimakan desert are important sources of aeolian dust and the emitted dust is considered to have influenced the Cenozoic climate throughout the northern hemisphere (Uno et al. 2009; Isozaki et al. 2020). It has been suggested that the dust particles, which can act as ice nuclei in high-altitude clouds, affect the global radiation budget by stimulating cirrus cloud formation, apart from influencing marine ecosystems by supplying nutrients to the ocean (Uno et al. 2009). Accordingly, it is essential to unravel the history of the desert. However, the time and manner of desertification remains controversial (Sun et al. 2009; Zheng et al. 2015; Heermance et al. 2018). Several causes are proposed to explain of the Cenozoic aridification of inland Asia such as the stepwise global cooling, the retreat of the Paratethys Sea, and the uplift of the Tibetan Plateau and surrounding mountains (e.g., Dupont-Nivet et al. 2007; Ramstein et al. 1997; Manabe and Broccoli 1990). In the Tarim Basin, the uplift of the Pamir and consequent blocking of the intrusion of moist air from the Paratethys Sea is proposed as the cause of the aridification, yet this hypothesis has been inadequately tested (Sun and Liu 2018).
One of the reasons for the difficulty in examining the linkage between the aridification in the Tarim Basin and the tectonic movement in the Pamir is the large uncertainties in the estimated ages of the two events. Ages of tectonic events in the Pamir have been estimated in several ways, such as from timings of provenance changes in the Cenozoic sequence along the southwestern margin of the Tarim Basin (e.g., Cao et al. 2014; Blayney et al. 2016), through the reconstruction of the thermal history of rocks exposed in the Pamir by using thermochronological methods such as biotite and muscovite $\mathrm{Ar} / \mathrm{Ar}$ dating and zircon and apatite (U-Th-Sm)/He dating (e.g., Sobel and Dumitru 1997), and through the calculation of the subsidence rate from the geological subsurface structure on the basis of seismic reflection data and geological mapping (e.g., Jiang and Li 2014; Chapman et al. 2017). These studies have suggested that major tectonic events occurred at different times, namely from the late Oligocene to the early Miocene, at the middle Miocene, and from the late Miocene to the early Pliocene (e.g., Sobel et al. 2013; Rutte et al. 2017). On the other hand, the timing of the desertification has been estimated from the appearance of aeolian deposits in Cenozoic terrestrial sequences of the Tarim Basin (Zheng et al. 2006, 2010, 2015; Sun et al. 2009; Tada et al. 2010; Sun et al. 2011; Sun and Windley 2015; Heermance et al. 2018). Because of the difficulty in constructing age models of terrestrial sequences, the estimated age of the initial aridification event in the Tarim

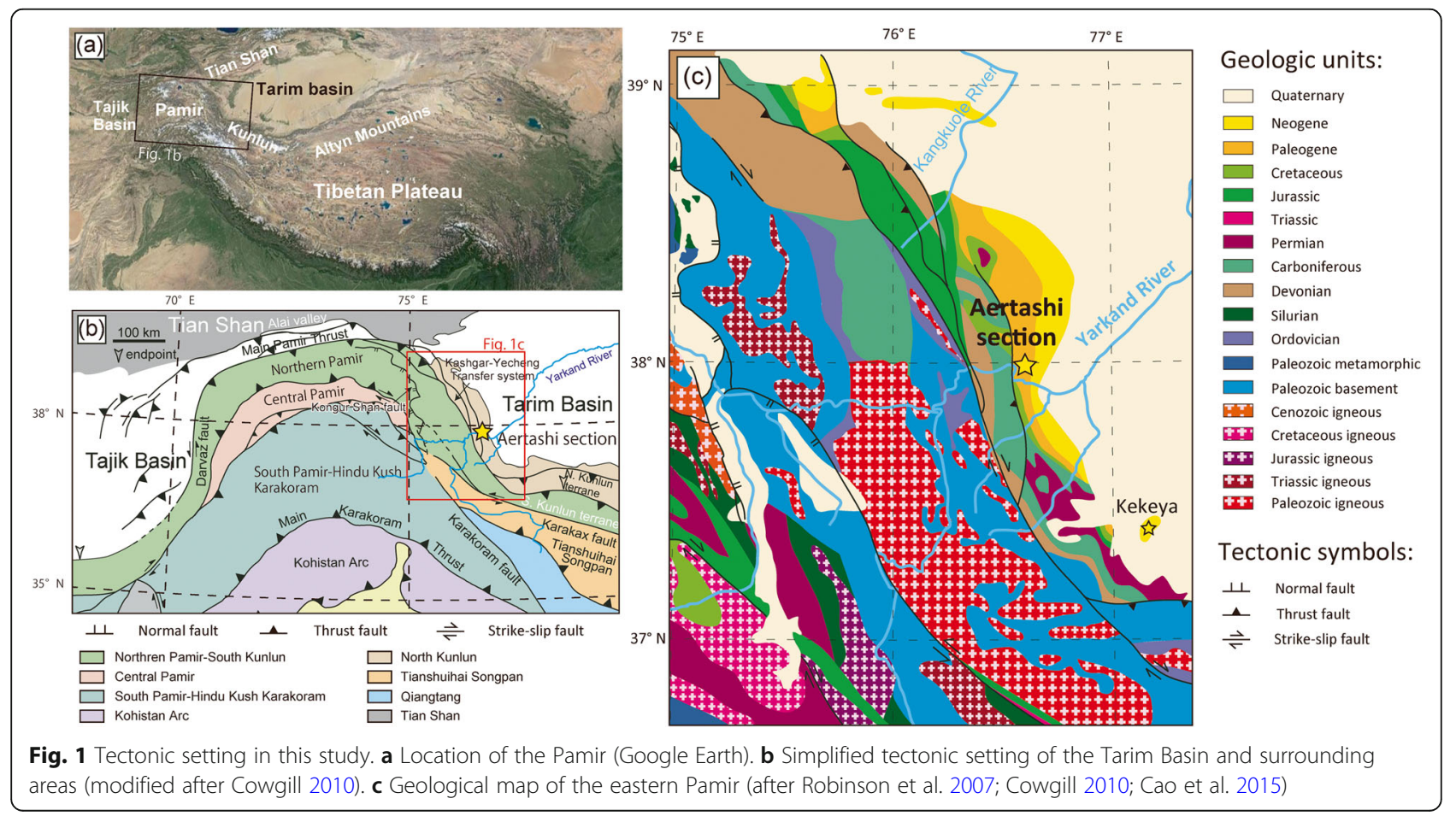


Basin ranges widely from the late Oligocene to the Pliocene (Sun et al. 2009; Tada et al. 2010; Sun et al. 2011; Sun and Windley 2015; Zheng et al. 2015; Heermance et al. 2018). Furthermore, the estimated ages of both aridification events of the Tarim Basin and tectonic events of the Pamir have errors of several million years typically, and the order of events is yet to be shown. Examining the timing of the two events within the same sedimentary sequence would be an ideal way to avoid such a correlation problem.

The provenance of fluvial deposits, whose drainage includes active tectonic belts such as the Pamir, is commonly used to specify the timing of the tectonic events (e.g., Najman 2006; Cao et al. 2014, 2015). To elucidate the evolution of the Pamir, previous studies have presented provenance data such as U-Pb zircon age distributions, detrital apatite fission track ages, and $\mathrm{Sm} / \mathrm{Nd}$ isotope ratios of sediments from Cenozoic sequences along the western margin of the Tarim Basin (Sobel and Dumitru 1997; Bershaw et al. 2012; Cao et al. 2014, 2015; Blayney et al. 2016; Clift et al. 2017). Although these studies showed that provenance changes occurred from the late Oligocene to the middle Miocene approximately at the same time as the onset of the deposition of thick conglomerate layers at the western edge of the Tarim Basin, exact ages have not been well constrained because of the low sampling resolution resulting from the time-consuming nature of the analyses used in previous studies. For the examination of the relationship between the aridification of the Tarim Basin and the uplift of the Pamir, it would be effective to investigate provenance changes in terrestrial sequences that have also preserved the evidence of aridification in the Tarim Basin by a new simple method which facilitates the analysis of many samples in a short time. In this study, we used the electron spin resonance (ESR) signal intensity and the Crystallinity Index (CI) of quartz for investigating the provenance changes. The ESR signal intensity correlates with the total natural radiation dose of quartz, which increases with age (Toyoda and Hattori 2000), and the CI of quartz depends on the formation speed and temperature of the quartz crystals (Murata and Norman 1976). They are expected to be suitable proxies for the investigation of the provenance changes of fluvial deposits.

In this study, we examined provenance changes in the late Eocene to early Miocene fluvial sequence of the Aertashi section, located in the southwestern margin of the Tarim Basin, to detect changes in the drainage basin, from which we inferred timings of tectonic events. The ESR signal intensity and CI of quartz were analyzed for the $64-500 \mu \mathrm{m}$ fraction of the fluvial sandstone, which was assumed to be transported by the paleo-Yarkand river. In addition, we determined the grain composition of fluvial sandstones by clast counting using thin sections. Finally, we compared the timings of the tectonic events in the Pamir estimated from provenance changes of fluvial sediments with those of intensified aridification obtained on the basis of the occurrence of aeolian deposits in previous studies to examine the linkage between the uplift of the Pamir and the desertification in the Tarim Basin.

\section{Geological setting}

\subsection{Controversies of aridification in inland Asia}

To explain the Cenozoic aridification of inland Asia and the formation mechanisms of the Taklimakan desert, three hypotheses have been proposed. The first hypothesis is that stepwise global cooling since the middle Eocene (probably caused by the decrease in the atmospheric $\left.p \mathrm{CO}_{2}\right)$ affected the regional climate (Dupont-Nivet et al. 2007; Bosboom et al. 2014b). Climate modeling studies showed that the change in atmospheric $p \mathrm{CO}_{2}$ altered the atmospheric heat distribution and hydrological cycle, leading to less precipitation in inland Asia (Zoura et al. 2019). The second hypothesis is that the westward retreat of the Paratethys Sea during the late Eocene decreased moisture supply to inland Asia, causing aridification (Ramstein et al. 1997; Bougeois et al. 2018; Kaya et al. 2019). The retreat of the Paratethys Sea could have been caused by both decrease in the global eustatic sea level and change in geography due to the uplift of the Tibetan Plateau (e.g., Bosboom et al. 2014b). The last hypothesis is that uplift of the Tibetan Plateau and the surrounding areas of the Tarim Basin, caused by the collision between the Eurasian continent and the Indian sub-continent, blocked moisture supply from the Paratethys sea and/or the Indian Ocean (Manabe and Broccoli 1990; Kutzbuch et al. 1993; An et al. 2001; Sun et al. 2017; Li et al. 2018; Sun and Liu 2018). In addition to the blocking effect, high mountain ranges cause the formation of stationary wave troughs, which also leads to the aridification in inland Asia (Manabe and Broccoli 1990). The uplift of the Pamir is especially significant among the mountains surrounding the Tarim Basin in driving the aridification, owing to its rain shadow effects blocking moisture from the west (Sun and Liu 2018). The Pamir gained high elevation during the late Cenozoic (Burtman and Molnar 1993) and this high elevation might have blocked the intrusion of the low-level westerlies into the Tarim Basin, leading to the aridification in the basin (Bosboom et al. 2014a; Sun et al. 2017). Although these hypotheses have been tested to some extent, a consensus is yet to be reached. In this study, we focused on third hypothesis and specifically tested the relationship between the desertification in the Tarim Basin and the uplift of the Pamir. 


\subsection{Tectonic setting of the studied area}

The Tarim Basin is located to the north side of the Tibetan Plateau and surrounded by the Pamir in the west, Kunlun Mountains in the south, Altyn Mountains in the southeast, and Tianshan Mountains in the north (Fig. 1a). The Cenozoic uplift of these mountains has been associated with the India-Asia collision that started at $\sim 60$ Ma (e.g., Sobel and Dumitru 1997; DeCelles et al. 2014; Kapp and Decelles 2019).

Fluvial sediments deposited along the southwestern margin of the Tarim Basin are interpreted to have been supplied mainly from the Pamir (Zheng et al. 2010; Cao et al. 2015; Blayney et al. 2016). The Pamir terranes form a large arcuate mountain belt bounded by the Tarim Basin on its east with the Kashgar-Yecheng Transfer System (KYTS), by the Tajik Basin on its west with the Darvaz fault, and by the Alai Valley on its north with the Main Pamir Thrust (Cowgill 2010) (Fig. 1b). The Pamir is divided into four east-west trending terranes separated by fault systems. From north to south these terranes are the North Pamir, Central Pamir, South Pamir, and Kohistan-Ladakh terranes, respectively. They were accreted during the late Paleozoic-Mesozoic, and each terrane has distinct geologic features (rock types, age, metamorphic grade, etc.) (Cowgill 2010; Robinson et al. 2007, 2012). Although studying the tectonic evolution of the Pamir is important for both understanding the continental collision process and examining its relationship with climatic change in the surrounding areas, when and how the tectonic events of the Pamir occurred during the Cenozoic continues to be debated (e.g., Sobel and Dumitru 1997; Blayney et al. 2016; Cowgill 2010; Cao et al. 2014; Chen et al. 2018; Wei et al. 2018). Two hypotheses have been proposed for the timing and nature of the tectonic event of the Pamir (e.g., Sobel and Dumitru 1997; Blayney et al. 2016; Cowgill 2010; Cao et al. 2014; Chen et al. 2018; Wei et al. 2018); one is that the Pamir salient was in line with the Kunlun Mountains before Oligocene times and started to move northward by $\sim 300 \mathrm{~km}$ since $\sim 25 \mathrm{Ma}$ (Cowgill 2010; Sobel et al. 2013; Blayney et al. 2016) and the other is that there existed an antecedent of the Pamir before the Cenozoic and its displacement relative to the Tarim Basin during the Cenozoic was only tens of kilometers (Chen et al. 2018; Wei et al. 2018; Li et al. 2020). Although the uplift history of the Pamir is controversial, previous studies have shown that there were several intervals during the Cenozoic when tectonic movements in the eastern part of the Pamir were active (e.g., Sobel et al. 2013). Early metamorphism in the South Pamir and its propagation to the Central Pamir during the late Eocene to the early Oligocene have been observed using Lu-Hf geochronology, U-Pb rutile thermochronology, and garnet thermometry, and these observations suggest that the formation of the Pamir deep crust started in late Eocene or before (Smit et al. 2014). From the late Oligocene to the early Miocene, the dextral KYTS has been suggested to have been active on the basis of the similar cooling ages observed over $\sim 250 \mathrm{~km}$ long belt at the southwestern edge of the Tarim Basin (Sobel and Dumitru 1997). Rapid exhumation of the Northern Pamir and Tianshan Mountains located to the north of the Pamir and the transition from thickening to exhumation of the domes located in the Central Pamir has also been reported during this time period, indicating the northward migration of the Pamir (Amidon and Hynek 2010; Bande et al. 2015; Stearns et al. 2015). In the late Miocene, the rapid exhumation of high-grade schists and gneisses in the footwall of the southern Kongur Shan fault in the eastern part of the Central Pamir is considered to be related to the initiation of east-west extension (Robinson et al. 2007). The initiation of the subduction of the Indian slab has been estimated to be at about $8 \mathrm{Ma}$ based on the tomography (Negredo et al. 2007). A thermochronological data set collected along the Yarkand River showed the cessation of the KYTS movement after 3-5 Ma (Sobel et al. 2011).

\subsection{Stratigraphy of the Aertashi section}

The Aertashi section $\left(37^{\circ} 58^{\prime} \mathrm{N}, 76^{\circ} 33^{\prime}-76^{\circ} 34^{\prime} \mathrm{E}\right)$ is located in the southwestern margin of the Tarim Basin (Fig. 1). The Cenozoic sedimentary sequence of the Aertashi section comprises four formations and one group, namely the Wulagen Formation, Bashibulake Formation, Wuqia Group, Artux Formation, and Xiyu Formation in ascending order (Zheng et al. 2015) (Fig. 2). The lithology of each formation is briefly summarized below on the basis of the field observations of this study, and partly, the summary is complemented by a description based on previous studies (Zheng et al. 2010, 2015; Bosboom et al. 2011; 2014a, b; Blayney et al. 2016, 2019; Wei et al. 2018).

The Wulagen Formation mainly consists of green mudstone intercalated with greenish-gray limestone rich in bivalve fossils and green fine sandstone. The thickness of this formation is ca. $80 \mathrm{~m}$ in the studied section. The depositional environment of this formation has been interpreted as nearshore to shallow marine on the basis of the fossil assemblages of bivalves, ostracods, calcareous nannofossils, and foraminifera (Bosboom et al. 2011; 2014a, b).

The Bashibulake Formation conformably overlies the Wulagen Formation with a sharp contact and its boundary is easily recognizable by a change from green to red color (Bosboom et al. 2011). The formation is characterized by alternations of decimeter thick, dominantly reddish-brown mudstone and red fine sandstone and subdivided into three units. In the lower unit of this 

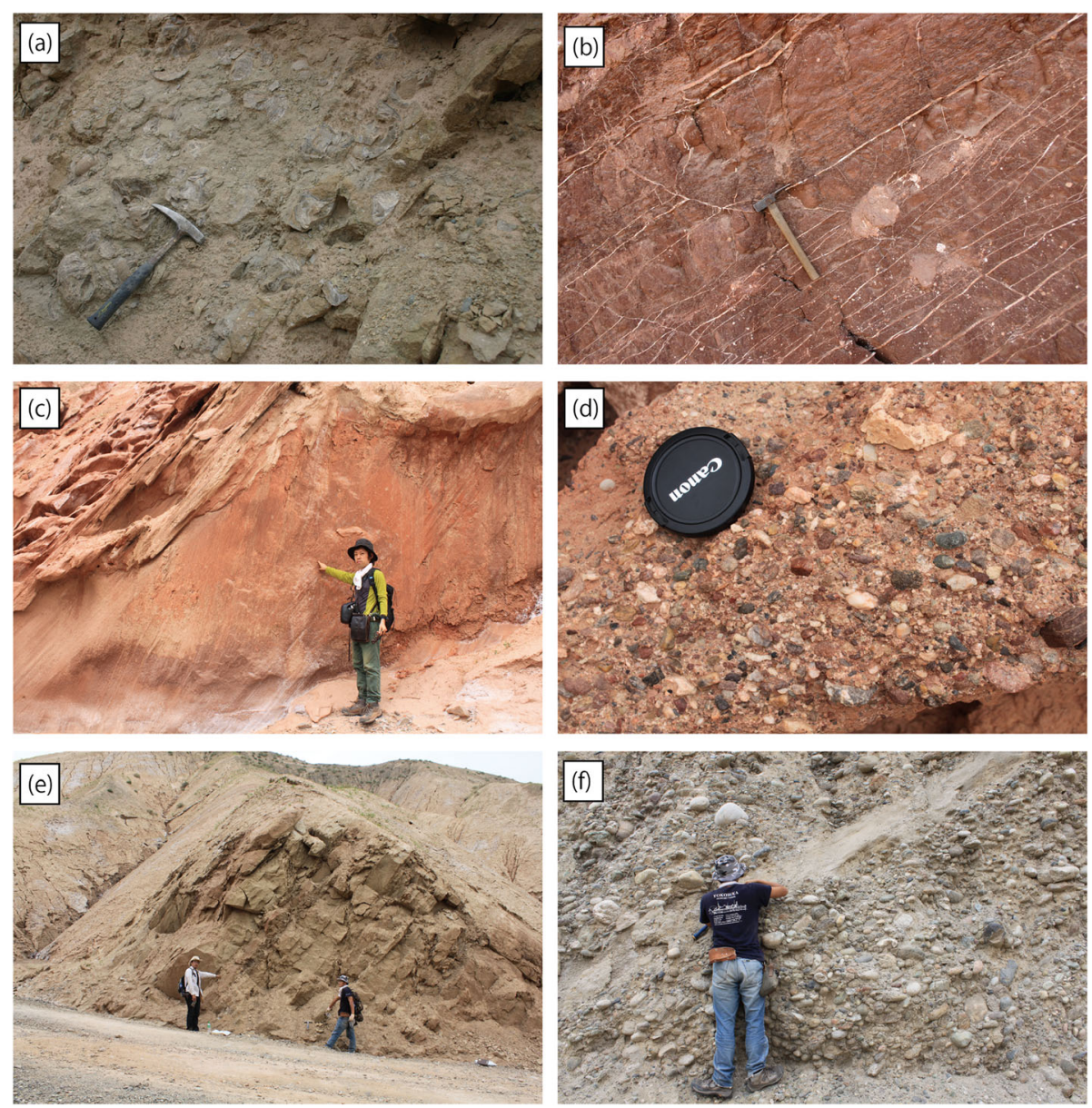

Fig. 2 Photographs showing the typical lithology of each formation. a Green mudstone with shell fossils of the Wulagen Formation. The shell height is $\sim 0.3 \mathrm{~m}$. b Reddish-brown mudstone containing gypsum veins of the Bashibulake Formation. Chicken-wire nodules of gypsum are also found in mudstones. c Aeolian sandstone showing high-angle cross-beddings at the bottom of the Wuqia Group. $\mathbf{d}$ Conglomerate of the lower part of the Artux Formation. The conglomerate is matrix-supported by fine sandstone and pebbles are sub-rounded to sub-angular and poorlysorted. e Alteration of orange and yellow fine sandstone of the upper part of the Artux Formation. $\mathbf{f}$ Thick conglomerate and intercalated light yellowish gray fine sandstone of the Xiyu Formation. The conglomerate comprises pebbles to cobbles of various rock types including basement rocks and volcanic rocks

formation, red fine sandstone often shows parallel laminations or trough cross laminations, which disappear upward. Desiccation cracks occasionally appear at the top of the mudstone layers and chicken wire gypsum is found within the mudstone in the middle unit of the formation. The upper unit of the formation dominantly comprises mudstone that sometimes shows pedogenic slickenside and red fine sandstone showing reverse grading. The thickness of this formation is ca. $850 \mathrm{~m}$. The depositional environment is interpreted to have changed from a nearshore lake, playa to a flood plain (Blayney et al. 2019; Zheng et al. 2010, 2015).

The Wuqia Group overlies the Bashibulake Formation unconformably (Zheng et al. 2015; Blayney et al. 2016, 2019) and is subdivided into three units characterized by alternations of red sandstone and reddish-brown mudstone. The lower unit of this group comprises 0.8 to $1 \mathrm{~m}$ thick well-sorted red fine sandstone beds that show high angle trough cross bedding, with rare reddish brown mudstone intercalations. Sandstones with large-scale cross beds of the lower unit are interpreted as the aeolian sand dune deposit (Zheng et al. 2010; Blayney et al. 2019). The thickness of the lower unit is ca. $150 \mathrm{~m}$. The middle unit comprises red fine sandstone intercalated with reddish-orange fine sandstone and brown mudstone. The reddish-orange fine sandstone shows an erosional contact with the red fine sandstone at its base, suggesting that the reddish-orange fine sandstone was formed under the influence of relatively strong current. The thickness of the middle unit is ca. $400 \mathrm{~m}$. The upper unit mainly comprises red fine sandstone and brown mudstone that are occasionally intercalated with yellow siltstone and gray fine sandstone with cross lamina. The sandstone beds show thickening in the upward direction 
through the upper unit. The thickness of the upper unit is ca. $550 \mathrm{~m}$. The sedimentary environment of the middle and upper units has been interpreted as a meandering river system (Zheng et al. 2010, 2015; Blayney et al. 2019). The total thickness of the group is ca. $1100 \mathrm{~m}$.

The Artux Formation conformably overlies the Wuqia Group, and its base is defined as the first appearance of pebble conglomerate. The formation is dominated by alternations of pink, orange, and yellow sandstone and red, reddish brown, and brown mudstone with pebble conglomerate intercalations. The formation is divided into two units on the basis of their lithology. The base of the lower unit is defined by the first appearance of a granule to pebble conglomerate bed which contains large limestone clasts up to $0.5 \mathrm{~m}$ in diameter (Zheng et al. 2010, 2015; Blayney et al. 2019). The lower unit comprises pinkish fine sandstone interbedded with granular to pebbly conglomerate and mudstone. Matrixsupported conglomerates occasionally show reverse grading which is a typical feature of debris flow deposits in alluvial fans. Furthermore, granule lenses and cross beddings are found within sandstone layers. These features suggest that this unit is a distal fan deposit (Zheng et al. 2010; Blayney et al. 2019). The thickness of the lower unit is ca. $700 \mathrm{~m}$. The upper unit is characterized by alternations of orange to yellow fine sandstone with ripple marks and reddish-brown mudstone with rare intercalation of granule layers. The granule layers occasionally erode the underlying layers in the upper part of the upper unit. Channels filled with trough cross-bedded sands with some floating pebbles are observed in this unit (Blayney et al. 2019). The thickness of the upper unit is ca. $1050 \mathrm{~m}$. The depositional environment has been interpreted as a distal alluvial fan with abundant crevasse and flood deposits (Zheng et al. 2010; Blayney et al. 2019). The total thickness of this formation is ca. $1750 \mathrm{~m}$.

The Xiyu Formation overlies the Artux Formation with a sharp flat contact. It is dominated by dark gray conglomerate that consist of poorly sorted, well-rounded pebbles to boulders, including basement rocks and volcanic rocks with a clast-supported fabric and rare medium sandstone intercalations with cross bedding (Blayney et al. 2019). From the sudden appearance of the conglomerate, the depositional environment of this formation has been interpreted as the middle to proximal alluvial fan (Zheng et al. 2010, 2015; Blayney et al. 2019; Wei et al. 2018). The thickness of this formation exceeds $5000 \mathrm{~m}$.

\subsection{Age model of the Aertashi section}

Three types of data are available to constrain the age model of the Aertashi section: biostratigraphy, U-Pb zircon chronology of volcanic material, and magnetostratigraphy (Yin et al. 2002; Bosboom et al. 2011; 2014a, b; Zheng et al. 2015; Wei et al. 2018). Bosboom et al. (2011, 2014a, b) estimated the age of the Wulagen Formation at several sections in the western Tarim Basin to determine the timing of the retreat of the Paratethys Sea. They identified foraminifera, ostracods, bivalves, calcareous nannofossils, and dinoflagellate cysts in the Wulagen Formation and concluded that the formation belongs to Zone CP14 (GTS2012) of calcareous nannofossil zonation on the basis of calcareous nannofossils and dinocyst assemblages (Bosboom et al. 2011, 2014a, b). Zheng et al. (2015) performed the dating of the ash layer from the upper part of the Xiyu Formation using ${ }^{40} \mathrm{Ar} /{ }^{39} \mathrm{Ar}$ dating of biotite grains and U-Pb dating of zircon grains, and the determined ages of the biotite and zircon grains were $11.49 \pm 0.34$ and $11.18 \pm$ $0.13 \mathrm{Ma}$, respectively. Since these ages were close to each other, they concluded that the eruption occurred around $11 \mathrm{Ma}$ and the ash was supplied instantaneously to the Aertashi section. Later, on the basis of petrographic, geochronological, and whole-rock geochemical evidence, Wei et al. (2018) found that the volcanic tuff was likely to have been derived from the Dunkeldik volcanic complex. Bosboom et al. (2014b), Zheng et al. (2015), and Blayney et al. (2019) conducted magnetostratigraphic studies at the Aertashi section and constructed magnetostratigraphy-based age models independently. All of these studies showed similar age models covering the interval from the late Eocene to the middle Miocene, with the maximum difference between these models being less than 0.5 million years. However, the sampling routes of Bosboom et al. (2014b) and Blayney et al. (2019) were partly different from the route of the current study, while that of Zheng et al. (2015) was identical. Therefore, in this study, we adopted the age model of Zheng et al. (2015). The Bashibulake Fm., Wuqia Gr., and Artux Fm. roughly correspond to the time intervals of the late Eocene, Oligocene, and early Miocene (Zheng et al. 2015), respectively.

\subsection{Previous provenance study in the Aertashi section}

Blayney et al. $(2016,2019)$ showed the temporal changes in the detrital zircon age distribution and mudstone Sm$\mathrm{Nd}$ ratio in the Aertashi section and interpreted that the provenance of fluvial sediments shifted four times. At $25 \mathrm{Ma}$, the negative shift of $\varepsilon \mathrm{Nd}$ values showed the first provenance change. Second shift at the bottom of the Xiyu Fm $(\sim 14 \mathrm{Ma})$ is marked by the sudden increase of zircons supplied from the North Pamir terrane in addition to the zircons from the Western Kunlun Mountains. The $<11 \mathrm{Ma}$ sample shows resemblance to the modern sample suggesting that the third shift of the provenance occurred in the middle of the Xiyu Fm. The detrital zircons in the modern Yarkand River draining in 
the Aertashi area indicate the increase in supply from South Pamir, suggesting that the fourth provenance change occurred after $11 \mathrm{Ma}$ (Blayney et al. 2016).

\section{Samples and methods}

\subsection{Samples for analyses}

Approximately $200 \mathrm{~g}$ of samples were collected throughout the Aertashi section at stratigraphic intervals of $\sim 50$ $\mathrm{m}$ during field surveys conducted in 2007 and 2010. For the reconstruction of the river drainage evolution and the determination of the effect of tectonics, fifty-nine fluvial fine sandstone samples were selected for ESR and CI analyses to determine the provenance of quartz grains. Twenty-seven sandstone and conglomerate samples were selected for thin section observations to identify rock types exposed in drainage basin. The sandstone samples covered the entire sequence from the base of the Bashibulake Formation to the base of the Xiyu Formation. The sampling location and stratigraphic position of each sample are presented in Supplementary Table 1.

\subsection{Pre-treatment of samples for ESR and $\mathrm{Cl}$ analyses}

Prior to ESR and CI analyses, carbonate, iron and manganese oxides, and organic matter were removed from the samples through chemical treatments to isolate detrital components and to remove elements that interfere with the $\mathrm{E}_{1}{ }^{\prime}$ center signal (Tada et al. 2000). Approximately $2 \mathrm{~g}$ of disaggregated samples were treated with $40 \mathrm{ml}$ of $20 \mathrm{vol} \%$ acetic acid solution at $40{ }^{\circ} \mathrm{C}$ for $2 \mathrm{~h}$ to remove carbonate. To remove iron and manganese oxides, the samples were treated with $40 \mathrm{ml}$ of $0.3 \mathrm{M}$ sodium citrate solution, $5 \mathrm{ml}$ of $1.0 \mathrm{M}$ sodium bicarbonate solution, and $1.5 \mathrm{~g}$ of sodium dithionite at $80{ }^{\circ} \mathrm{C}$. Organic matter was removed by treating the samples with $40 \mathrm{ml}$ of $10 \mathrm{vol} \%$ hydrogen peroxide solution at $60{ }^{\circ} \mathrm{C}$ for $10 \mathrm{~h}$.

Grain size distributions of all the samples subject to the ESR and CI analyses were measured to characterize the fraction used for the analyses, since the fluvial sandstone was contaminated with aeolian dust. The grain size measurement was conducted at room temperature using a laser diffraction particle size analyzer (Malvern Panalytical, Mastersizer 2000) at the University of Tokyo. Approximately $50 \mathrm{mg}$ of a homogeneous aliquot of each pre-treated sample was emptied into the analyzer filled with deionized water and circulated in a closed transport circuit. Each sample was ultrasonicated for $5 \mathrm{~min}$ before the measurement and stirred at 2000 rpm throughout the measurement to disperse the particles. For each sample, the measurement was repeated five times and the result was averaged. The measurement was conducted for the diameter range $0.02-2000$ $\mu \mathrm{m}$. The reproducibility was better than $\pm 1.0 \mu \mathrm{m}$ for the median diameter in five measurements of a standard sample of soda lime glass beads (UB-911L, UNITIKA Ltd.). The Mie model was used for the determining grain size distributions from raw diffraction patterns. The values of 1.590 and 1.0 were used for the real and imaginary parts of the complex refractive index, respectively (Nagashima et al. 2016).

All of the fluvial sandstone samples showed multimodal grain size distributions. Grain size distribution of selected representative samples are shown in Fig. 3 and all data are presented in Supplementary Table 2. In general, the multimodal distribution of fluvial sandstone comprises several log normal distributions that represent the transportation of sets of particles through different mechanisms such as suspension, saltation, and bottom traction (e.g., Ashley 1978; Sun et al. 2002). Thus, numerical partitioning into subcomponents of log normal distributions was conducted using the GRG Non-linear solution tool of MS Excel, which is installed by default. All of our samples showed three modes, and the squared sum of residual errors when we decomposed into three subcomponents was acceptable for all the samples. The median diameters of these three subpopulations were in the ranges $1.3-18.8,6.4-118$, and $38.8-301 \mu \mathrm{m}$ and the averages of these median diameters were 7.1, 41.4, and $115 \mu \mathrm{m}$, respectively. In modern Taklimakan desert, it has been shown that fine silt particles of the dry rivers and dry lakes along the outer margin of the alluvial fans and of the dry lakes in the Tarim Basin have been eroded and transported by surface wind, resulting in the particles contaminating the river sand in the southwestern margin of the Tarim Basin (Isozaki et al. 2020). The coarsest fraction, which roughly corresponds to the 64$500 \mu \mathrm{m}$ (fine to medium sand) fraction, is coarser than the subpopulation representing the eolian dust in modern Taklimakan desert and it is considered as representing particles derived from exposed host rocks in the drainage basin and transported by bottom traction in the river (Isozaki et al. 2020). Therefore, in this study, the $64-500 \mu \mathrm{m}$ fraction was extracted from a bulk sample by sieving and used for the ESR and CI analyses to avoid the effect of contamination by aeolian dust particles.

\subsection{ESR and $\mathrm{Cl}$ analyses}

The ESR signal intensity and CI of quartz in $64-500 \mu \mathrm{m}$ fraction of fluvial sandstone in the Aertashi section was measured to examine provenance changes. Generally, quartz is the most abundant mineral in sandstones, and it is resistant to physical and chemical weathering. Furthermore, its specific gravity (= density) is close to that of bulk sediments. Consequently, it is less influenced by weathering and sorting during transportation and best represents bulk sediments. Thus, it is an ideal material for use in provenance analysis. 

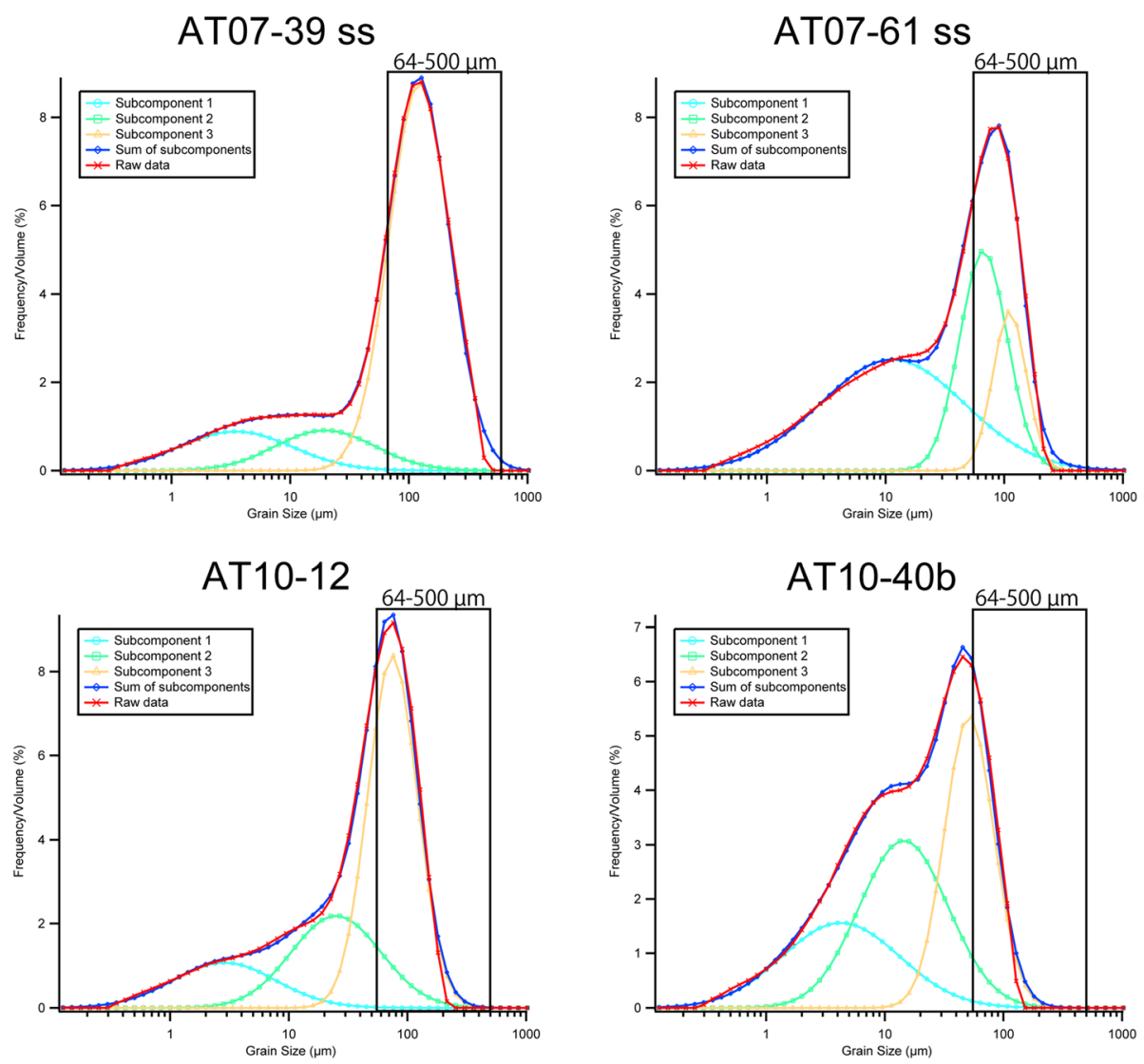

Fig. 3 Typical grain size distributions of representative samples. Measured data is indicated in red, and the three identified sub-components are indicated in blue, yellow, and green. The 64-500 $\mu \mathrm{m}$ fraction used for the ESR and $\mathrm{Cl}$ analyses in this study corresponds to the coarsest sub-population

The number of lattice defects with unpaired electrons of minerals can be evaluated by the ESR signal intensity of the $E_{1}{ }^{\prime}$ center (Toyoda 1992). The $E_{1}{ }^{\prime}$ center of quartz is an unpaired electron in single silicon $\mathrm{sp}^{3}$ orbit oriented along a bond direction into an oxygen vacancy (Feigl et al. 1974) and used to estimate the amount of oxygen vacancies in quartz, which increases with the age of quartz grains (Toyoda and Hattori 2000). Namely, high (low) value of the ESR signal intensity of quartz suggests that quartz grains were supplied from old (young) host rocks. To measure the ESR signal intensity of quartz, first, the $64-500 \mu \mathrm{m}$ fractions of pretreated samples were irradiated with gamma ray (total dose of 2.5 kGy) using a ${ }^{60} \mathrm{Co}$ source at Takasaki Advanced Radiation Research Institute, National Institutes for Quantum and Radiological Science and Technology to create hole centers. Then, approximately $0.1 \mathrm{~g}$ of irradiated samples is heated at $300{ }^{\circ} \mathrm{C}$ for $15 \mathrm{~min}$ to convert the oxygen vacancies to $\mathrm{E}_{1}{ }^{\prime}$ center. The ESR signal intensity was measured at room temperature with $\mathrm{X}$-band ESR spectrometer (JEOL, JES-FA100) at the University of Tokyo under $0.01 \mathrm{~mW}$ of microwave power, $0.1 \mathrm{mT}$ magnetic field modulation $(100 \mathrm{kHz}), 5 \mathrm{mT}$ scan range, 2 min scan time, and $0.03 \mathrm{~s}$ time constant. The ESR signal intensity is expressed in spin units ( 1 spin unit = $1.3 \times 10^{15} \mathrm{spins} / \mathrm{g}$ ) (Toyoda and Naruse 2002).

The quartz content (QC) was measured by the internal standard method (Klug and Alexander 1974) with silicon powder (Wako Pure Chemical Industries, Ltd.) as an internal standard, using PANalytical X'Pert PRO X-ray diffractometer (XRD) at the University of Tokyo with $\mathrm{Cu}$ target. The measurement condition was set as the tube voltage of $45 \mathrm{kV}$, the tube current of $40 \mathrm{~mA}$, the slit of $1^{\circ}$, scanning interval of 20 to 30 ${ }^{\circ} 2 \theta$, the time per step(s) of 6.35 , and scan speed of $0.334 \%$. The error of the quartz content estimation is better than $\pm 8.5 \mathrm{wt} \%$.

The CI of quartz defined by Murata and Norman (1976) was calculated from the X-ray diffraction data. The CI measurement was also conducted using the same $\mathrm{XRD}$ as is used for the QC measurement. The measurement condition was set as the tube voltage of $45 \mathrm{kV}$, the tube current of $40 \mathrm{~mA}$, the slit of $1^{\circ}$, scanning interval of 65 to $75^{\circ} 2 \theta$, the time per step(s) of 22.86 , and scan 
speed of $0.02321 \%$ s. The error of the CI for the three repeated measurements is better than \pm 0.25 .

\subsection{Observation of thin sections}

Thin section observations of fluvial sandstone and conglomerate obtained from the Aertashi section were performed to determine the exposed rock types in the drainage basin. Thirty-eight samples were impregnated with epoxy resins Devcon ET-300 and Petropoxy 154, and thin sections of the impregnated samples were prepared. The grain components of all the thin section samples are observed to identify types of clasts. Seven samples selected to cover the entire sequence were point-counted at a step of $0.5 \mathrm{~mm}$. At least 500 points, excluding the matrix and pore space, were counted for every sample.

\section{Results}

4.1 Results of the ESR signal intensity and the $\mathrm{Cl}$ analyses The temporal change in the ESR signal intensity of quartz in the $64-500 \mu \mathrm{m}$ fraction is shown in Fig. 4a. The ESR signal intensity ranges from 4.0 to 18.7 , with the average of 10.9 and the standard deviation of 3.4, respectively. The ESR signal intensity fluctuates between 5.4 and 11.8 from the $0 \mathrm{~m}$ level at the base of the Bashibulake Fm. to the $1500 \mathrm{~m}$ level in the middle part of the Wuqia Gr. At the $1500 \mathrm{~m}$ level that coincides with the first appearance of yellow siltstone, which is interpreted as aeolian loess in the Kekeya section (Zheng et al. 2015), the ESR signal intensity abruptly increases to 15.6. The ESR signal intensity ranges between 13.0 and 18.7 from the $1500 \mathrm{~m}$ level to the $2200 \mathrm{~m}$ level in the lower part of the Artux Fm. Between the $2200 \mathrm{~m}$ and $3000 \mathrm{~m}$ levels in the middle part of the Artux Fm., the ESR signal intensity fluctuates significantly between 7.4 and 18.5 . Between the $3000 \mathrm{~m}$ and $3600 \mathrm{~m}$ levels in the upper part of the Artux Fm., the ESR signal intensity decreases again and fluctuates with smaller amplitude between 9.0 and 12.6. At the $3600 \mathrm{~m}$ level at the base of the Xiyu Fm., the ESR signal intensity suddenly decreases to 4.0.

The temporal change in the CI of quartz in the 64$500 \mu \mathrm{m}$ fraction is shown in Fig. $4 \mathrm{~b}$. The $\mathrm{CI}$ ranges between 7.15 and 8.44 with the average of 8.05 and the standard deviation of 0.27 . The CI shows a low value between 7.15 and 8.06 from the $0 \mathrm{~m}$ level to the $800 \mathrm{~m}$

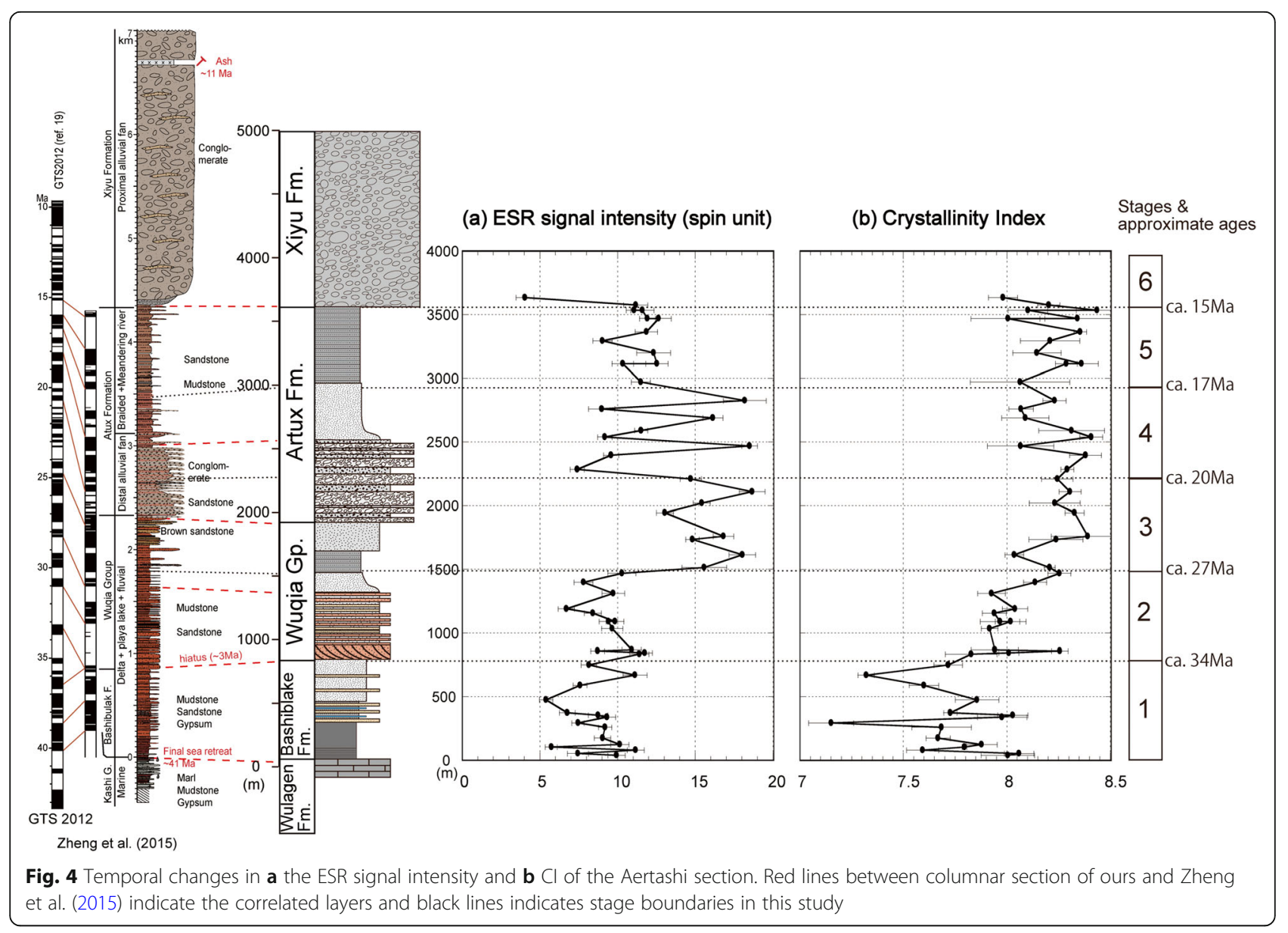


level in the Bashibulake Fm. From the boundary between the Bashibulake Fm. and the Wuqia Gr. at the $800 \mathrm{~m}$ level, the $\mathrm{CI}$ starts to increase gradually up to the level of $1500 \mathrm{~m}$ at which the CI reaches approximately 8.2. Above the level of $1500 \mathrm{~m}$, the CI fluctuates between 7.98 and 8.44 .

On the basis of the temporal trend in the ESR signal intensity and $\mathrm{CI}$, the temporal variation in provenances can be divided into six stages, from stages 1 to 6 in the ascending order (Fig. 4).

Stage 1 (ca. 39-34Ma) corresponds to the Bashibulake $\mathrm{Fm}$. whose stratigraphic interval ranges from the $0 \mathrm{~m}$ level to the $800 \mathrm{~m}$ level. In this stage, the ESR signal intensity shows a relatively low value, ranging from 5.4 to 11.2 with an average of 8.5 and a standard deviation of 1.8 , and the CI shows low values ranging from 7.15 to 8.06 with an average of 7.74 and a standard deviation of 0.26 .

Stage 2 (ca. 34-27 Ma) corresponds to the lower to middle part of the Wuqia Gr, ranging from 800 to 1500 $\mathrm{m}$ in stratigraphic level. Because of the probable hiatus at the boundary between stages 1 and 2, the actual boundary age cannot be constrained between 37 and 34 $\mathrm{Ma}$. We tentatively defined the stage boundary as $34 \mathrm{Ma}$ when the ESR signal intensity and CI started to change. The boundary between stages 1 and 2 is defined by the start of a long-term gradual increase in the $\mathrm{CI}$, which coincides with the unconformable boundary between the Bashibulake Fm. and the Wuqia Gr. In stage 2, the ESR signal intensity remains low values ranging from 6.7 to 11.8 with an average of 9.5 and a standard deviation of 1.5 , while the CI gradually increases from 7.83 to 8.26 with an average of 8.02 and a standard deviation of 0.13 .

Stage 3 (ca. 27-20 Ma) corresponds to the upper part of the Wuqia Gr. and the lower part of the Artux Fm. and ranges from 1500 to $2200 \mathrm{~m}$ in stratigraphic level. The boundary between stages 2 and 3 is marked by an abrupt increase in the ESR signal intensity at ca. $1500 \mathrm{~m}$, which coincides with the first appearance of the yellow siltstone interpreted as loess (Zheng et al. 2015). In stage 3 , the ESR signal intensity shows a high value ranging from 13.0 to 18.7 with an average of 15.5 and a standard deviation of 1.9 , while the CI stops increasing and shows relatively high and stable values between 8.04 and 8.39 with an average value of 8.25 and a standard deviation of 0.11 .

Stage 4 (ca. 20-17 Ma) corresponds to the middle part of the Artux Fm. from 2200 to 3000 m in stratigraphic level. At the boundary between stages 3 and 4, the ESR signal intensity starts to oscillate with a large amplitude, which ranges between 7.4 and 18.5 and has an average value of 12.4 and a standard deviation of 4.5 , while the CI remains stable ranging between 8.04 and 8.41 with an average value of 8.23 and a standard deviation of 0.14 .
Stage 5 (ca. 17-15 Ma) corresponds to the upper part of the Artux Fm., from 3000 to $3600 \mathrm{~m}$ in stratigraphic level. The boundary between stages 4 and 5 is defined by the ESR signal intensity beginning to have stable values. In stage 5, the ESR signal intensity remains stable and has moderate values ranging from 9.0 to 12.6 with an average value of 11.5 and a standard deviation of 1.1 . The CI also maintains stable high values ranging from 8.01 to 8.44 with an average value of 8.23 and a standard deviation of 9.14 .

Stage 6 (ca. < $15 \mathrm{Ma}$ ) corresponds to the lower part of the Xiyu Fm. above $3600 \mathrm{~m}$ in stratigraphic level. At the boundary between stages 5 and 6 , the abrupt decrease in the ESR signal intensity occurs. In stage 6, the ESR signal intensity shows a low value of 4.0, while the CI is 7.98 , which is similar to the values in the underlying stage 5 . Although only one sample was analyzed in this stage, other proxies such as lithic compositions obtained in this study and zircon age distributions presented by Blayney et al. (2016) support a significant provenance change at the boundary between stages 5 and 6 (details will be discussed in Section 5).

\subsection{Thin section observations}

Before point counting, grain components such as detrital minerals and lithic fragments in samples were identified from 38 thin sections, to examine the rock types exposed in the source areas. Characteristics of each type of clast are described below. The grain composition was determined from the point counting result and is described below as per total grains.

Quartz is the most dominant mineral in all the samples examined. Three types of quartz grains are identified: monocrystalline, polycrystalline, and chalcedonic. Monocrystalline quartz is the most dominant type of quartz in all the samples examined, and its maximum and minimum content were 61.9 and $24.9 \%$, respectively, with the average of $51.0 \%$; it accounts for more than two-thirds of quartz grains. About half of the monocrystalline quartz grains shows wavy extinction. Polycrystalline quartz is also commonly found in the studied samples, and its maximum and minimum contents are $10.3 \%$ and $3.6 \%$, respectively, with the average of $6.0 \%$. It shows unclear crystal boundary and contains various crystal sizes ranging from silt size to coarse sand size. Colorless chalcedonic quartz without impurities is rarely found.

Feldspar is the second most dominant detrital mineral and accounts for a relatively small percentage, with the maximum and minimum contents are $17.8 \%$ and $6.8 \%$, respectively, with the average of $11.6 \%$. Three types of feldspar grains are identified: orthoclase, plagioclase, and microcline. Orthoclase grains are far more abundant (average 10.3\%) than plagioclase (average 0.8\%) and 
microcline (average $0.5 \%$ ) grains and their relative ratios vary slightly among samples.

Accessory detrital minerals such as micas, mafic minerals, and opaque minerals are found in small amounts (average: $3.4 \%$ ). Biotite is the most common accessory detrital mineral and is especially abundant in the Xiyu Fm. Biotite grains in this formation are relatively large $(\sim 500 \mu \mathrm{m})$. Other accessory detrital mineral grains are silt sized and weathered, which rendered their identification difficult.

Lithic fragments are classified into six groups: (1) limestone lithics, (2) mudstone lithics, (3) sandstone lithics, (4) chert lithics, (5) volcanic lithics, and (6) metamorphic lithics (Fig. 5). Plutonic lithic fragment is not observed in the thin sections, possibly because the grain size of samples is smaller than the size of crystals in plutonic rocks.

Limestone lithics account for $1.3-17.0 \%$ with the average of $7.5 \%$. They mostly comprise micritic calcite with some detrital quartz grains (Fig. 5a). Fossil imprints such as foraminifera are occasionally observed in limestone lithics. Furthermore, limestone lithic fragments are indented by other clastic grains and show concave contacts because of pressure solution.

Mudstone lithics account for $0.7-17.6 \%$ with the average of $6.3 \%$. Four types of mudstone lithic fragments are found. Siltstone lithic comprises silt-sized grains of quartz and feldspar along with a small amount of the matrix composed of clay minerals, iron oxides, and other clay-sized particles (Fig. 6a). Siliceous siltstone lithic consists of silt-sized quartz grains with microcrystalline quartz cement (Fig. 6b). The sorting of siliceous siltstone is good. Claystone lithic consists mostly of clay-size clay minerals, iron oxides and other minerals with rare siltsize quartz grains (Fig. 6c). Siliceous claystone lithic mostly comprises silt-sized detrital quartz grains cemented with microcrystalline quartz along with minor iron oxides and opaque minerals (Fig. 6d).

Sandstone lithics accounts for $0 \sim 4.8 \%$ with an average of $1.4 \%$. Some samples do not contain sandstone lithics because of their small grain sizes. Four types of sandstone lithic fragments are identified. Quartzo-feldspathic
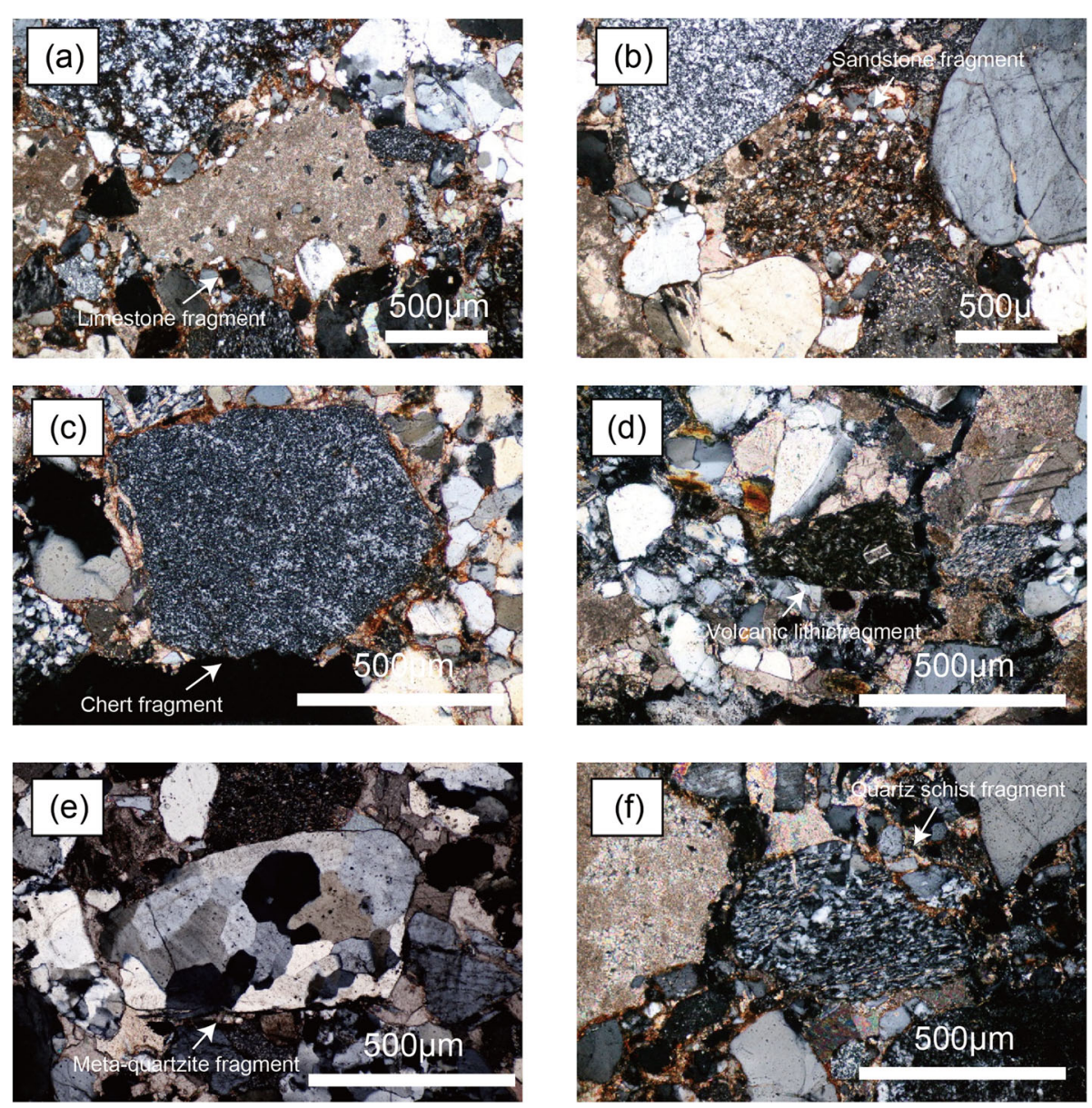

Fig. 5 Optical microscope photographs of various types of lithic fragments in the Aertashi section (all photographs were taken under crossed nicols). a Micritic limestone, b Sandstone, c Chert, $\mathbf{d}$ Volcanic rock, e Meta-quartzite, and $\mathbf{f}$ Quartz schist fragments 

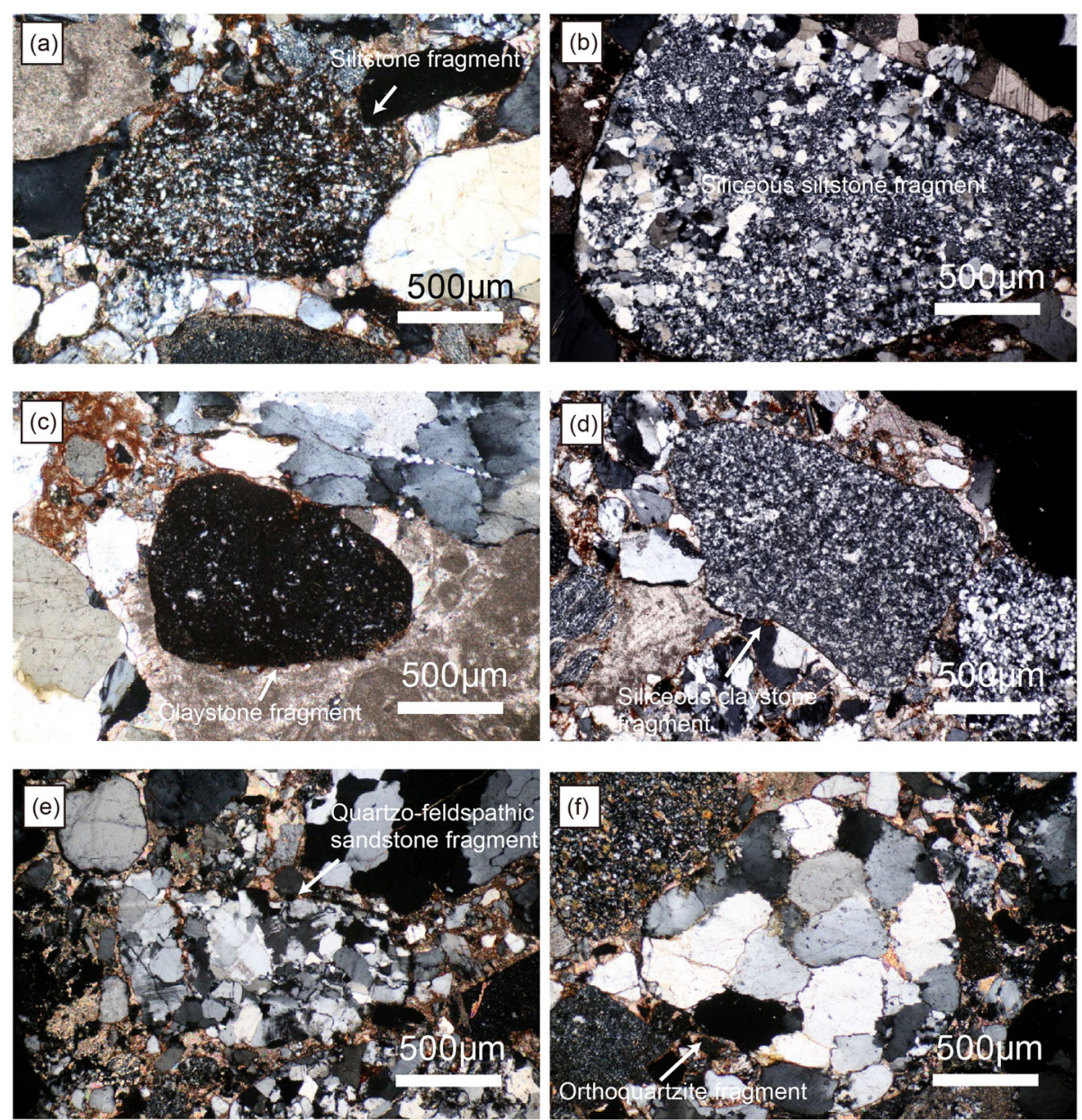

Fig. 6 Optical microscope photographs of clastic rock fragments in the Aertashi section (all photos are taken under crossed nicols). a Siltstone, $\mathbf{b}$ Siliceous siltstone, c Claystone, $\mathbf{d}$ Siliceous claystone, e Quartzo-feldspathic sandstone, and $\mathbf{f}$ Orthoquartzite fragments

sandstone lithic dominantly comprises quartz with minor feldspar (Fig. 6e). It is poorly sorted, but the matrix is rare. Ortho-quartzite lithic consists of wellsorted and rounded single crystal quartz grains (Fig. $6 \mathrm{f}$ ). Calcite cement is observed in a small amount. The grain contacts are generally concave-convex and sutured. Siliceous sandstone lithics mostly comprises quartz grains with minor lithic fragments and feldspar. Their microcrystalline quartz cement content is $\sim 30 \%$. Siliceous sandstone lithics are often subjected to weathering, and therefore, they contain secondary minerals. Quartz wacke lithic consists of quartz grains with an abundant $(\sim 50 \%)$ matrix of clay minerals and other clay-sized particles (Fig. 5b).

Chert lithic is less common compared with other sedimentary rock lithics and its content ranges from 0.9 to $5.2 \%$, with the average of $2.4 \%$. Its microcrystalline quartz cement content exceeds more than $95 \%$, and it contains rare clay-sized particles of other detrital minerals such as clay minerals and opaque minerals (Fig. 5c). Quartz crystals are less than $64 \mu \mathrm{m}$ and the grain boundary appears irregular, although it is not clear because of small crystal size.

Volcanic lithics are rare $(<3 \%)$ and found mostly in the Xiyu Fm. They mainly contain a few tabular or needle-shaped euhedral phenocrysts in an opaque groundmass (Fig. 5d). Blayney et al. (2016) reported that in sandstones from the Wuqia Gr. to the Artux Fm. in the Aertashi section, the volcanic fragment content exceeded $50 \%$. However, their observation is not consistent with our observation, namely volcanic fragments are rarely found in samples extracted from the Bashiblake Fm. to the Artux Fm. Gravels in the conglomerate of the Artux Fm. dominantly comprises limestone and sandstone with minor igneous and metamorphic rocks (Blayney et al. 2019). Thus, it is unlikely that only sandstone samples contain large amounts of volcanic rock fragments.

Metamorphic lithics include schist and meta-quartzite. Meta-quartzite lithic (average 5.2\%) is more abundant 
than schist lithic (average 0.3\%) (Fig. 5e). Schist lithics include quartz schist, pelitic schist, and psammitic schist lithics (Fig. 5f). Some of the meta-quartzite lithics are equigranular and have a straight grain boundary, while others comprise quartz grains of various size and show a unclear and wavy boundary, which are likely to be recrystallized.

Authigenic minerals occur mostly as cement that fills intergranular space, and they include calcite, iron oxides, and silica. Sparry calcite cement is the most abundant and iron oxide cement is the second most abundant.

\subsection{Temporal changes in grain composition of sandstone}

Temporal changes in the grain composition based on the point counting result are shown in Fig. 7. All the samples have less than $15 \%$ of matrix and are classified as lithic arenite which is consistent with a previous study of Blayney et al. (2016) (Fig. 7a). To identify changes in the types of source rocks, the Q-F-L plot is shown in Fig. $7 \mathrm{a}$ and the change in lithic composition is shown in Fig. $7 \mathrm{~b}$.

Sandstone samples from the Bashibulake Fm. to the Artux Fm. show relatively similar grain composition. They mainly comprise monocrystalline quartz with minor feldspar, lithic fragments, and rare accessory minerals. Common types of lithic fragments are siliciclastic rocks, limestone, chert, and metamorphic rocks. Only one sample from the Artux Fm. (AT07-52cgl) contains a small amount of volcanic rock fragments. Two samples from the lower part of the Wuqia Gr. (AT10-21 and AT10-24) show a high percentage (>10\%) of limestone fragments. The sample from the lower part of the Artux Fm. (AT07-52cgl) contains a larger amount of sandstone fragments, probably because of the larger grain size of the sandstone. The sample from the upper part of the Artux Fm. (AT07-61) contains relatively high amounts of accessory minerals (5.7\%), especially opaque minerals (3.6\%), which is more than twice those of other samples from the strata below the Artux Fm. On the other hand, the sample from the Xiyu Fm. (AT10-49a) show distinctly different composition compared with samples from other formations. It contains less detrital quartz (24.9\%) and more lithic fragments (54.8\%), which include $5.0 \%$ of volcanic lithic. Moreover, the percentage of accessory minerals $(11.8 \%)$ is more than twice that of other samples.

\section{Discussion}

\subsection{Sources of coarse detrital materials in fluvial sandstone}

As described in the previous section, the temporal variation in the provenance of the coarse detrital materials was divided into 6 stages. In the following, the sources of each stage will be discussed on the basis of the ESR and CI values of quartz grains as well as from a comparison with the composition of fluvial sandstones. To show the difference between different stages, a diagram that shows the ESR signal intensity vs. the CI relationship is presented in Fig. 8.

In stage 1, relatively large variations in the $\mathrm{CI}$ indicate multiple provenance sources. Considering the change in the sedimentary environment from a lagoon through a playa lake to a floodplain in the Bashibulake Fm. (Zheng et al. 2010), the site might not have been under the influence of a single stable river system. Clasts might have been occasionally transported along shore by coastal currents during this stage. The grain composition of fluvial sandstone suggests that fragments of sandstone, mudstone, limestone, chert, and metamorphic rocks were supplied from its drainage. On the other hand, no igneous rock fragments were observed in this stage. The ESR signal intensity of quartz lying between 5.4 and 11.2 suggests that the source rocks are probably Paleozoic in age (Toyoda and Hattori 2000), whereas the U-Pb age of zircon grains contained in fluvial sandstone ranges from Jurassic to Archean (Blayney et al. 2016). No modern river sediments having relatively large drainage basin in the eastern part of the Pamir show zircon age peaks around $1.9 \mathrm{Ga}$ and $300 \mathrm{Ma}$, which are observed for samples taken from the Bashibulake Fm. (Blayney et al. 2016), suggesting that at least some of the detrital grains in the Bashibulake Fm. were supplied from rocks that are not the main provenance of the modern river sediment. Moreover, the absence of volcanic lithic fragments in stage 1 sediments suggests that volcanic rocks were not exposed in the drainage basin and the river head did not reach the exposed Triassic volcanic rocks in the North Pamir terrane. Hence, the basin infill of Mesozoic Paleozoic sandstone, mudstone, and limestone exposed along the western edge of the Tarim Basin between the KYTS and the Aertashi section is the likely source of the fluvial sediment in the Aertashi section (Fig. 9). The age distribution of zircon grains in the basement rock of the southwestern Tarim Basin shows a peak around 1.9 Ga (Xu et al. 2013) and the modern Kangkuole River sand derived from the Jurassic sedimentary rock exposed along the southwestern edge of the Tarim Basin shows the peak of the zircon age distribution to be around $300 \mathrm{Ma}$ (Rittner et al. 2016). Although these areas are deeply eroded now and not the main source of the river sand of the modern Yarkand River (Blayney et al. 2016; Clift et al. 2017), these areas might have been the sources of zircon grains which cannot be explained by the supply from the Pamir.

In stage 2, the gradual increase in the CI suggests an increase in the relative contribution of a large amount of crystallized quartz. On the other hand, the low and stable values of the ESR signal intensity and the clast 
(a)

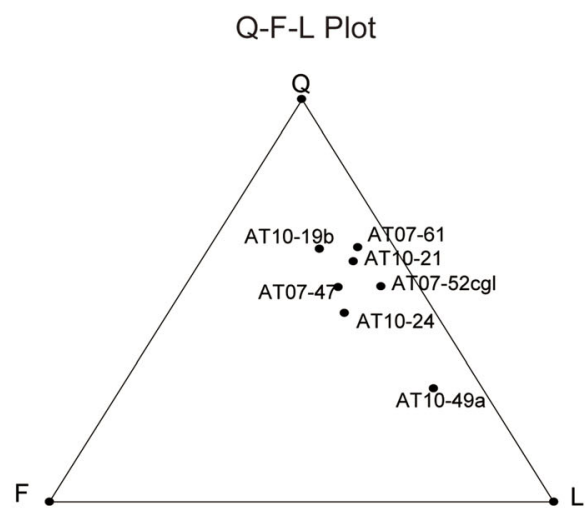

(b)

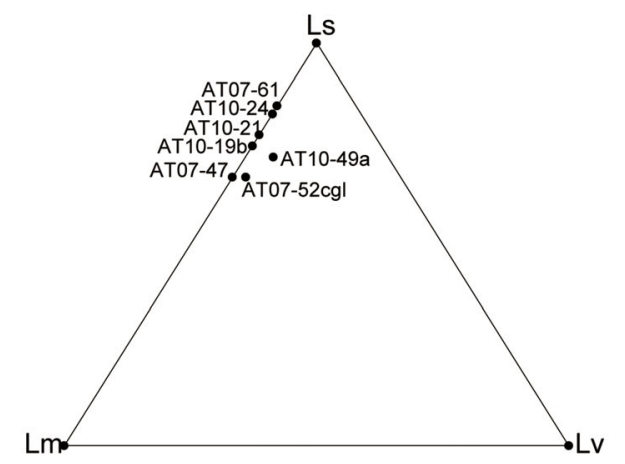

(c)

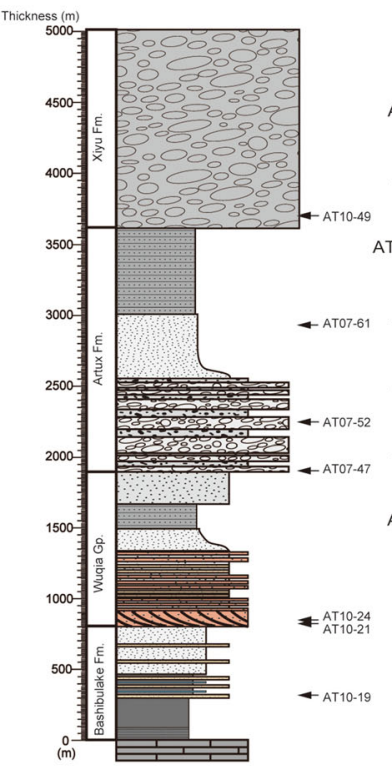

(d)

The change in grain composition

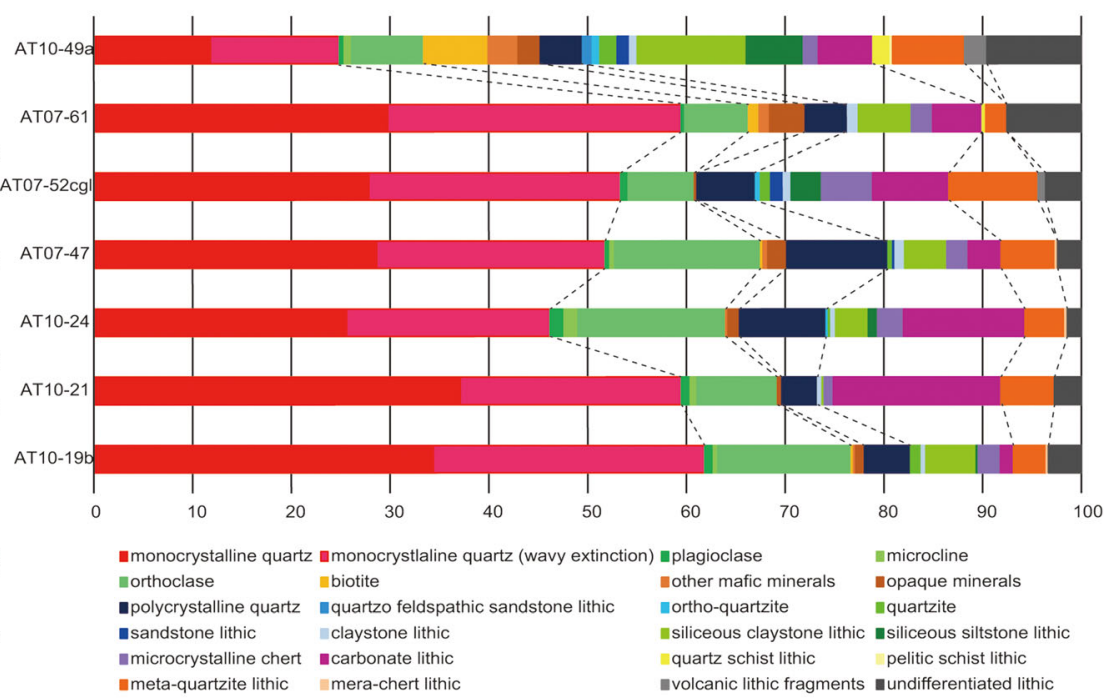

The change in lithic composition

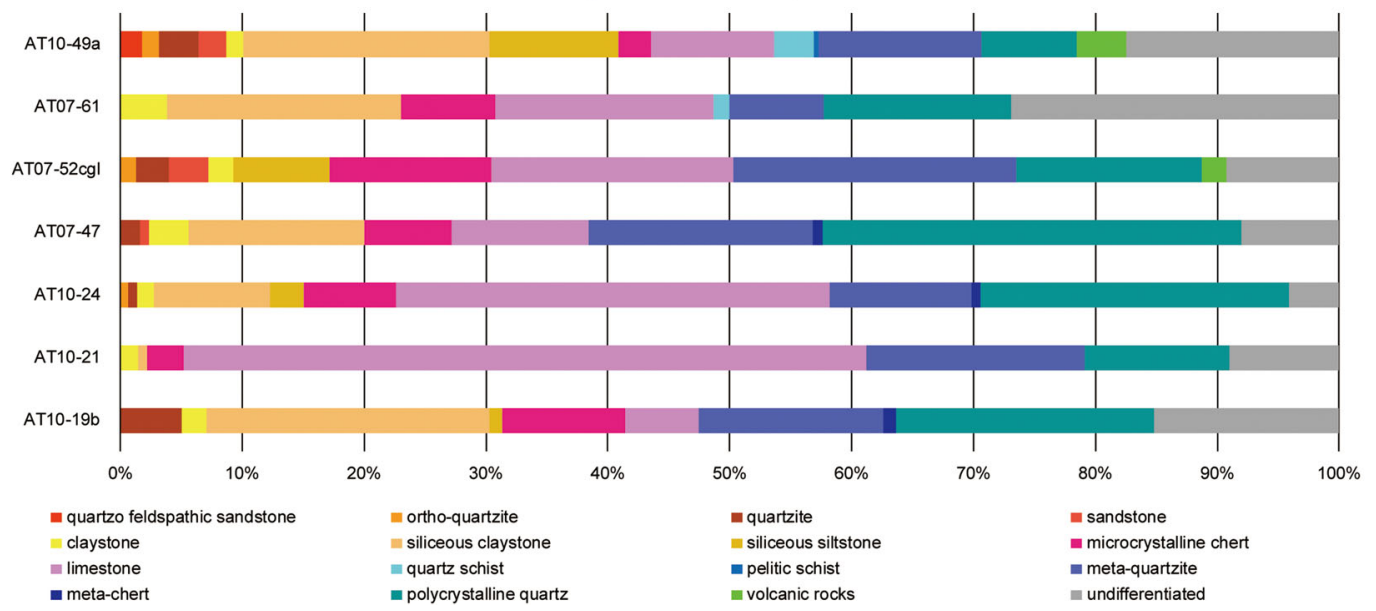

Fig. 7 Changes in grain composition. a Quartz-feldspar-lithic plot. b Lithic plot showing the ratio of sedimentary rocks, volcanic rocks, and metamorphic rocks. $\mathbf{c}$ Changes in grain compositions of fluvial sandstone in the Aertashi section. $\mathbf{d}$ Changes in lithic fragments in the Aertashi section 


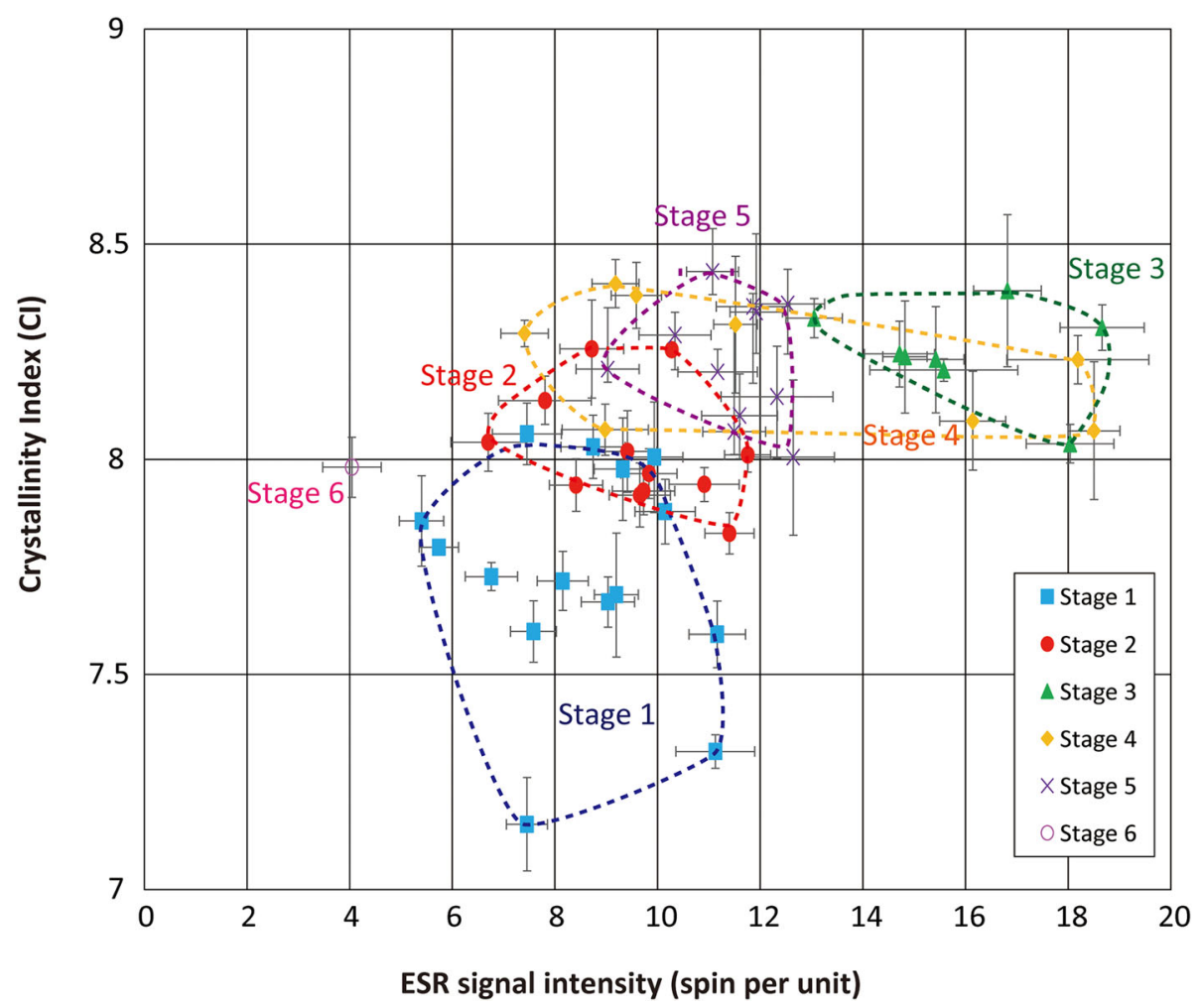

Fig. 8 ESR vs. Cl plot. The relationship between the ESR signal intensity and $\mathrm{Cl}$ of quartz for the fine sand fraction of fluvial sandstone in the Aertashi section. The stages are divided on the basis of the temporal variations of the ESR signal intensity and $\mathrm{Cl}$

composition being similar to stage 1 suggest that the provenance did not change significantly throughout stages 1 and 2 . These observations imply that the river gradually eroded and started to supply more crystallized rocks of the same rock types.

At the beginning of the stage 3, the abrupt increase in the ESR signal intensity and the relatively high CI suggest an increased contribution of source rocks containing older quartz grains. The lithic composition suggests that the rock types did not change significantly between stages 2 and 3, but weakly metamorphosed rocks such as meta-quartzite and polycrystalline quartz became dominant in addition to siliciclastic sedimentary rocks and limestones while igneous rocks and highly metamorphosed rocks were nearly absent in the source area. According to Blayney et al. (2019), Sm-Nd isotope values of mudstone also showed a sudden negative shift around the base of stage 3, indicating the appearance of more crustal source rocks. The change in the Sm-Nd isotope values in the study of Blayney et al. (2016) appears to be delayed relative to the change in the ESR signal intensity in the current study. However, the exact timing of the change is uncertain because the sampling interval of Blayney et al. (2016) was large. We guess that the time lag between the timings of changes in these proxies reflects the difference in grain size of the material analyzed (i.e., mudstones were used for the Sm-Nd analysis and sandstones were used for the ESR signal intensity analysis). It has been shown that in a single river sediment sample, particles with different sizes could have different sources (Saito et al. 2017). Paleozoic (meta)sedimentary rocks exposed in the North Pamir terrane are the oldest sedimentary rocks in the northeastern Pamir (Cowgill 2010) and are likely to be the source of rocks containing older quartz grains with a high ESR signal intensity characteristic of stage 3 (Fig. 9). While the ESR signal intensity changed considerably between stages 2 and 3, the types of lithic fragments, the CI, and the zircon age distribution did not change significantly (Blayney et al. 2016). Zircon grains are formed in igneous rocks and then eroded, transported, and incorporated into sediments. Age distributions of zircon grains in fluvial sediments reflect age distributions of igneous rocks in drainage basin, and the zircon age distribution in sedimentary rocks has multiple peaks in a wide range when zircon grains originate from multiple sources. In the eastern part of the Pamir where the main source of the paleo-Yarkand River is assumed to be located, the zircon ages in sedimentary rocks show a multimodal distribution (Blayney et al. 2016; Clift et al. 2017). It is conceivable to mask the provenance change between stages 2 and 3 . 

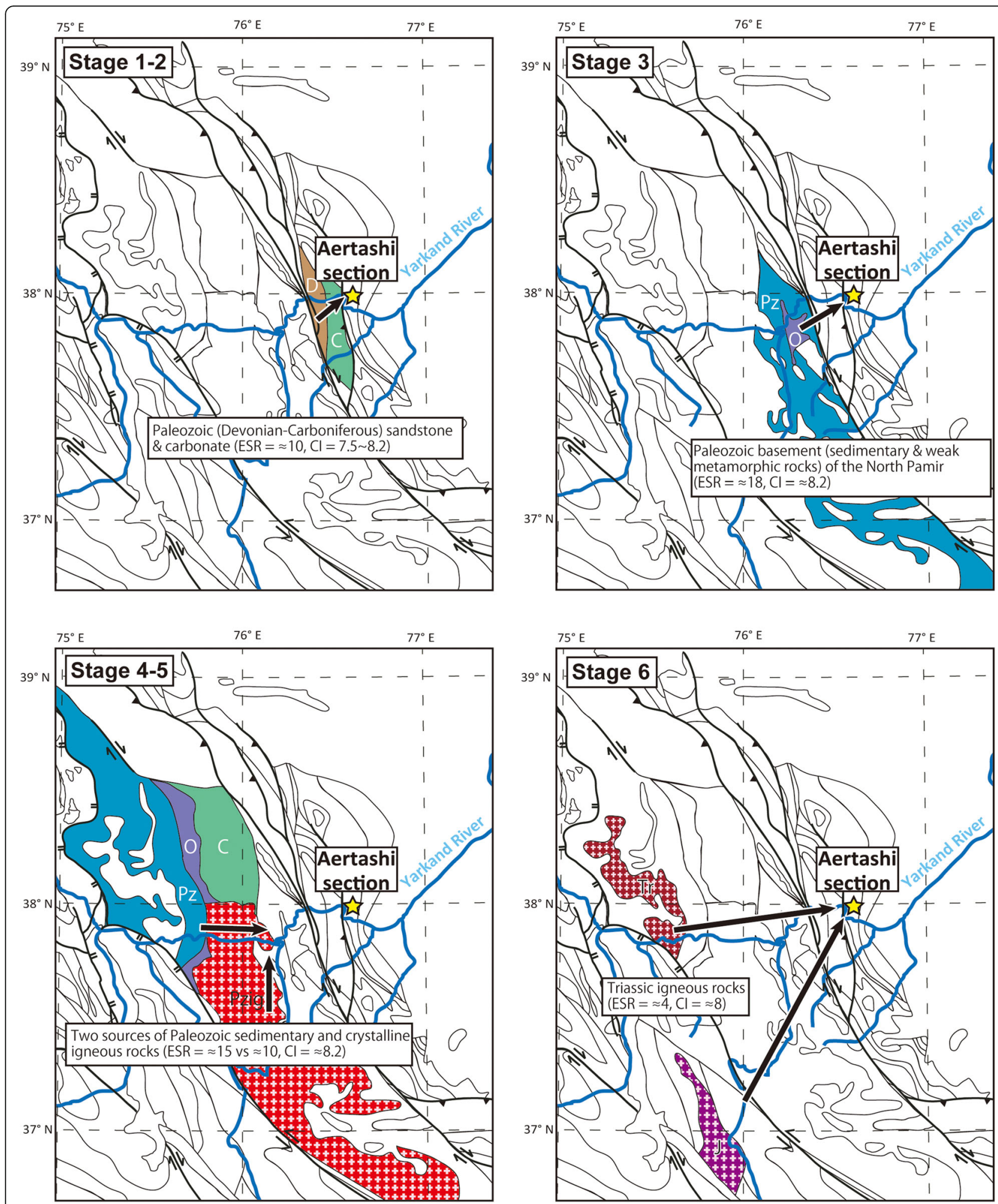

Fig. 9 Acquired drainage of the paleo-Yarkand River during each stage 
In stage 4, the ESR signal intensity vs. CI plots fall into two groups, one is similar to those of stage 3 and the other is similar to those of stage 5 (Fig. 8). Thus, oscillations in the ESR signal intensity in stage 4 are interpreted as reflecting repeated switching of provenance between the two distinctly different sources characteristic of stages 3 and 5 during this period.

In stage 5, the stable and moderate ESR signal intensity and the stable high CI values suggest that the provenance is stable and corresponds to one of the two sources of stage 4 (Fig. 9). Furthermore, the accessory minerals such as biotite and mafic minerals increase compared with earlier stages and schist fragments begin to appear for the first time in the studied sequence, suggesting the appearance of igneous and metamorphic source rocks containing more accessory minerals. This in turn implies that the paleo-Yarkand River acquired new drainage in the North Pamir where these rocks are exposed (Cowgill 2010). However, assemblages of other grains and lithic fragments do not change significantly, suggesting that the main source area is similar to that in the earlier stages.

In stage 6, the ESR signal intensity and grain composition indicate that the source rocks of fluvial sediments changed drastically compared with those of stage 5 . The low ESR signal intensity value suggests that the average age of quartz grains in the source rocks decreased, probably corresponding to the Mesozoic or younger (Toyoda and Hattori 2000). According to the thin section observations, the grain composition of the fluvial sandstone of the Xiyu Fm. changed significantly from that of the Artux Fm., showing a wider variety of lithic fragments such as volcanics and schists, apart from sandstones, limestones, and a small amount of weakly metamorphosed rocks in the Artux Fm. This suggests that the paleo-Yarkand River acquired the new drainage in the Pamir where additional types of host rocks including volcanic rocks and schists were exposed. Moreover, the percentage of biotite increases abruptly at the beginning of stage 6 , indicating that the detrital supply of acidic igneous rock fragments containing large biotite crystals started in stage 6 . In the area to the east of the KYTS, acidic igneous rocks are not exposed. Therefore, it is expected that the river drainage reached the area near Kongur Shan fault where Mesozoic igneous rocks are exposed (Fig. 9). This is consistent with the zircon age distribution pattern of sandstone in stage 6 showing distinctive peaks of early Mesozoic, which are attributed to igneous rocks exposed in the North Pamir terrane on the basis of their resemblance to those in modern river sediments supplied from the North Pamir terrane (Blayney et al. 2016; Wei et al. 2018).

\subsection{Causes of provenance changes}

The transition from stage 1 to stage 2 at ca. $34 \mathrm{Ma}$ is marked by a relatively small change in the $\mathrm{CI}$ and might have reflected the appearance of the steady area of the drainage basin. Since the area of the drainage basin does not appear to have changed significantly as suggested by the little change in the ESR signal intensity, grain composition, and the age distribution of zircon grains (Blayney et al. 2016), a sudden significant tectonic movement is unlikely to have occurred in the drainage of the paleoYarkand River between stages 1 and 2. The beginning of the increase in the CI at the base of stage 2 might be attributed to gradual unroofing and the consequent increase in the supply of more crystallized rocks in the drainage. Rapid global cooling that occurred around 34 $\mathrm{Ma}$ at the Eocene-Oligocene boundary and the associated sea level drop could have changed the hydrology in inland Asia (Dupont-Nivet et al. 2007; Li et al. 2018; Zoura et al. 2019) and this might have led to the establishment of paleo-Yarkand River draining stably within the area to the west of the KYTS and possible hiatus (Bosboom et al. 2014a, b). Although there are few studies on the climatic change in the Pamir during the Eocene-Oligocene transition (EOT), it is unlikely that the gradual intensification of precipitation occurred at that time considering the aridification in inland Asia at that time (e.g., Dupont-Nivet et al. 2007). On the other hand, it has been reported that deformation of the metamorphic domes in the Central and South Pamir started in the Eocene and the metamorphism prograded northward during late Eocene to Oligocene (Smit et al. 2014; Stearns et al. 2015). Thus, we suggest that the gradual uplift of the Pamir, rather than increase in precipitation, is more likely to be the cause for unroofing and the consequent increase in the CI during stage 2.

At the boundary between stage 2 and stage 3 (ca. 27 $\mathrm{Ma}$ ), host rocks containing older quartz grains of metasedimentary rock origin derived from the eastern part of the North Pamir terrane suddenly appeared, suggesting that the paleo-Yarkand River acquired a new drainage basin with new source rocks in a short period. There are two possible reasons for the river to supply fragments of older source rocks. One is that the river acquired a new drainage basin upstream, where older meta-sedimentary rocks were exposed. The other is that the underlying older strata were newly exposed in the same drainage basin because of the uplift and subsequent rapid erosion within the same drainage basin. The latter possibility is less plausible because the Mesozoic-Paleozoic strata to the east of the Pamir are relatively thick and the dip angle is very large (Cowgill 2010). Therefore, we prefer the first possibility that the river head of the paleoYarkand River extended into the North Pamir terrane and the river acquired a new drainage basin at the 
beginning of stage 3, which is likely to have resulted from the uplift of the eastern North Pamir terrane associated with the fault movement surrounding the North Pamir (Sobel and Dumitru 1997; Bershaw et al. 2012; Cao et al. 2015). The appearance of the conglomerate lagging behind the sudden increase in the ESR signal intensity suggests that tectonic movement first occurred near the river head in the North Pamir terrane and propagated toward the depositional site of the Aertashi section. In the surrounding areas of the Pamir, evidence for tectonic events was examined using other methods such as geothermometer and seismic refraction, and the evidence suggested the existence of tectonic activity near the Pamir during the late Oligocene to the early Miocene (e.g., Sobel et al. 2013; Jiang and Li 2014). Thermal modeling based on the (U-Th)/He dating of zircon and apatite showed that the exhumation rate in the North Pamir accelerated during the early Miocene (Amidon and Hynek 2010). In the Tian Shan Mountains located to the north of the Pamir, a rapid exhumation event during the early Miocene was suggested on the basis of apatite fission track data (Bande et al. 2015). Bande et al. (2015) further suggested that the north-south trend shortening occurred in the area surrounding the Pamir at ca. $25 \mathrm{Ma}$ because of the activation of the TalasFergana faults, one of the largest faults in the area.

In stage 4, the onset of the fluctuation of provenance between two sources suggests that the drainage basin expanded in the upper stream of the paleo-Yarkand River and started to provide younger clastics at ca. $20 \mathrm{Ma}$. The tectonic activity such as the initiation of the fault movement in the eastern Pamir is likely to have occurred around ca. 20 Ma. In fact, Sobel and Dumitru (1997) dated clasts of fluvial sediment along the piedmont of the Western Kunlun Shan by apatite fission track and found that cooling ages were roughly $20 \mathrm{Ma}$, which was interpreted to be associated with the KYTS activity.

A steady drainage basin was probably established at ca. $17 \mathrm{Ma}$, judging from the stable values of the ESR signal intensity and $\mathrm{CI}$ in stage 5 . This stage is interpreted to have been an interval of less intense tectonic activity.

The largest change in the drainage occurred at the boundary between stages 5 and 6 (ca. $15 \mathrm{Ma}$ ), and it was characterized by significant changes in the ESR signal intensity, grain composition, and lithology as well as $\mathrm{U}-\mathrm{Pb}$ age distribution of zircon grains and $\mathrm{Sm}-\mathrm{Nd}$ isotope values (Blayney et al. 2016). Deposition of the thick pebble conglomerate of the Xiyu Fm. suggests that the Aertashi section was located in the middle of the alluvial fan and that the mountain range of the Pamir came closer to the section. This, in turn, strongly suggests that the deposition of the Xiyu Fm. started when a wide area in the North Pamir terrane, including the new drainage in the western part where Mesozoic igneous rocks were exposed, was uplifted (e.g., Blayney et al. 2016; Wei et al. 2018; Zheng et al. 2006). Acquisition of the new source is expected to have been caused by the uplift of the North Pamir.

\subsection{Relationship between uplift of the Pamir and aridification in the Tarim Basin}

In previous studies, the timing of the aridification in the Tarim Basin was estimated on the basis of the first occurrence of sand dune or loess deposit in Cenozoic sequences (Sun et al. 2009; Zheng et al. 2015; Heermance et al. 2018). In the Aertashi section, the deposition of sand dune sediments started from the bottom of the Wuqia Gr. at ca. 34 Ma (Blayney et al. 2019), indicating relatively dry condition with poor vegetation. On the other hand, the result of this study suggests that the provenance of fluvial sediments did not change significantly during stages 1 and 2 (ca. 39-34 Ma), indicating that significant tectonic events that affected the drainage of the paleo-Yarkand River did not occur in the Pamir in association with the aridification in the Tarim Basin. In other words, the initial aridification in the Tarim Basin occurred before significant tectonic activity started in the Pamir. The sudden appearance of the aeolian dune sand is likely to be related to the global cooling at the EOT. In fact, it has been reported that the rapid climate change at the EOT affected the climate and vegetation in the other parts of inland Asia (Sun et al., 2014; Dupont-Nivet et al. 2007), and it is conceivable that the climate in the Tarim Basin was also affected. Gradual subsidence could have changed the position of the Aertashi section relative to the Pamir and its depositional environment (Blayney et al. 2019).

In the Kekeya section, which is also located at the southwestern edge of the Tarim Basin, aeolian silt deposition started in the Artux Fm. at 26.7-22.6 Ma and loess deposition continued through the Artux and Xiyu Fm. (Tada et al. 2010 with the new age model; Zheng et al. 2015), although there is little clear evidence of loess deposition in the Aertashi section because of the continuous presence of the persistent river system. From this evidence, it is interpreted that the Tarim Basin has been continuously under arid conditions at least since the deposition of the Artux Fm. (Zheng et al. 2010, 2015). The timing of the onset of loess deposition in the Kekeya section is close to the boundary between stages 2 and 3 at ca. $27 \mathrm{Ma}$, which is much later than the initial deposition of sand dune deposit in the Aertashi section (Zheng et al. 2015). Approximately $27 \mathrm{Ma}$ is close to the timing of the provenance change of fluvial sediments in the Aertashi section between stages 2 and 3. Thus, the tectonic event in the North Pamir that occurred at the boundary between stages 2 and 3 might have been associated with the intensification of the dry conditions in 
the Tarim Basin. It is also worth to note that the active tectonic uplift in the North Pamir is expected to have supplied a large amount of the detrital materials to the Tarim basin, which should have acted as a source of aeolian dust and desert sand (Zheng 2016; Isozaki et al. 2020). In fact, onset of loess deposition occurred at the latest Oligocene not only in the Tarim Basin but also in the western Chinese Loess Plateau and Junggar Basin (Sun et al. 2010; Qiang et al. 2011). Further research of the paleo-environment in the Tarim Basin is necessary for a more detailed discussion on the linkage between the aridification in the Tarim Basin and the uplift of the Pamir.

\section{Conclusions}

ESR signal intensity and CI analyses of detrital quartz and thin section observations were performed for fluvial sandstones obtained from the Aertashi section at the southwestern edge of the Tarim Basin to examine provenance changes in the drainage basin of the paleoYarkand River. The result suggests that the provenance of fluvial sediments at the Aertashi section is marked by five times shift approximately at $34 \mathrm{Ma}, 27 \mathrm{Ma}, 20 \mathrm{Ma}$, $17 \mathrm{Ma}$, and $15 \mathrm{Ma}$, and on the basis of this observation, we divided the sequence into six provenance stages. Thin section observations of the fluvial sandstones showed that the rocks exposed in the drainage basin were predominantly sandstone, mudstone, limestone, and chert throughout the sequence. The contribution of metamorphic rocks and volcanic rocks started to increase in stage 6. A sudden increase in the ratio of volcanic lithic fragments and biotite at the boundary between stages 5 and 6 at ca. 15 Ma suggests the expansion of the drainage basin and acquisition of new source rocks such as volcanic rocks and granitic plutonic rocks that were exposed in the North Pamir terrane. The results of this study and a previous provenance study (Blayney et al. 2016) indicate that major tectonic events in the NE Pamir occurred at ca. $27 \mathrm{Ma}$, ca. $20 \mathrm{Ma}$, and ca. $15 \mathrm{Ma}$. On the other hand, the first appearance of desert dunes at ca. 34 Ma in the Aertashi section (Zheng et al. 2010; Blayney et al. 2019) precedes the major tectonic events in the NE Pamir unraveled in this study. Thus, the climate in the Tarim Basin was already arid before the major tectonic events in the NE Pamir. However, the subsequent uplift of the NE Pamir at $27 \mathrm{Ma}$ may have intensified the aridification because it is observed to be coeval with the initiation of loess deposition in the Kekeya section (Tada et al. 2010). Testing the arid conditions in the Tarim Basin by methods such as chemical index of alteration (CIA), clay mineral, and pollen analyses can help us to examine the relationship between the timing of the tectonic movements in the
Pamir and the aridification in the Tarim Basin more precisely in future studies.

\section{Abbreviations}

ESR: Electron spin resonance; Cl: Crystallinity Index; KYTS: Kasugar-Yecheng transfer system; Fm.: Formation; Gr.: Group; EOT: Eocene-Oligocene transition

\section{Supplementary Information}

The online version contains supplementary material available at https://doi. org/10.1186/s40645-021-00427-6.

\section{Additional file 1.}

Additional file 2

Acknowledgements

We thank the staff at the Takasaki Advanced Radiation Research Institute, National Institute for Quantum and Radiological Science and Technology (QST) for the assistance with $\gamma$-ray irradiation.

\section{Authors' contributions}

RT proposed the topic, conceived, and designed the study. AS carried out the experiment, analyzed the data, and wrote the manuscript. TY, HS, NS, AK, $\mathrm{KW}$, and $\mathrm{HZ}$ collaborated with the corresponding author in the construction of manuscript. All authors read and approved the final manuscript.

\section{Funding}

This work was jointly supported by the National Natural Science Foundation of China (NSFC) (U1902208, 41991323, and 4188101) to the Strategic Priority Research Program of Chinese Academy of Sciences (XDB26020301), and the Second Tibetan Plateau Scientific Expedition and Research (2019QZKK0704) to Hongbo Zheng

\section{Availability of data and materials}

The datasets analyzed during the current study are available from the corresponding author on reasonable request.

\section{Declaration}

Competing interests

The authors declare that they have no competing interest.

\section{Author details}

${ }^{1}$ Department of Earth and Planetary Science, Graduate School of Science, The University of Tokyo, 7-3-1 Hongo, Bunkyo-ku, Tokyo 113-0033, Japan. ${ }^{2}$ Institute for Geo-Cosmology, Chiba Institute of Technology, 2-17-1 Tsudanuma, Narashino, Chiba 275-0016, Japan. ${ }^{3}$ Yunnan Key Laboratory of Earth System Science, Yunnan University, Kunming 650500, People's Republic of China. ${ }^{4}$ Department of Global Environment and Disaster Prevention, Faculty of Science and Technology, Kochi University, Akebono-cho 2-5-1, Kochi 780-8520, Japan. ${ }^{5}$ Department of Geology and Paleontology, National Museum of Nature and Science, 4-1-1, Amakubo, Tsukuba, Ibaraki 305-0005, Japan. ${ }^{6}$ School of Earth and Environmental Sciences, The University of Queensland, Brisbane, Queensland 4072, Australia.

Received: 15 July 2020 Accepted: 12 May 2021

Published online: 05 August 2021

\section{References}

Amidon WH, Hynek SA (2010) Exhumational history of the north central Pamir. Tectonics 29(5):1-13. https://doi.org/10.1029/2009TC002589

An Z, Kutzbach JE, Prell WL, Porter SC (2001) Evolution of Asian monsoons and phased uplift of the Himalaya-Tibetan plateau since Late Miocene times. Nature 411(6833):62-66. https://doi.org/10.1038/35075035

Ashley GM (1978) Interpretaetion of polymodal sediments. J Geol 86(4):411-421. https://doi.org/10.1086/649710

Bande A, Sobel ER, Mikolaichuk A, Acosta VT (2015) Talas-Fergana Fault Cenozoic timing of deformation and its relation to Pamir indentation. Geol Soc London, Spec Publ 427(1):295-311. https://doi.org/10.1144/SP427.1 
Bershaw J, Garzione CN, Schoenbohm L, Gehrels G, Tao L (2012) Cenozoic evolution of the Pamir plateau based on stratigraphy, zircon provenance, and stable isotopes of foreland basin sediments at Oytag (Wuyitake) in the Tarim Basin (west China). J Asian Earth Sci 44:136-148. https://doi.org/10.101 6/j.jseaes.2011.04.020

Blayney T, Dupont-Nivet G, Najman Y, Proust JN, Meijer N, Roperch P, Sobel ER, Millar I, Guo Z (2019) Tectonic evolution of the Pamir recorded in the Western Tarim Basin (China): sedimentologic and magnetostratigraphic analyses of the Aertashi section. Tectonics 38(2):492-515. https://doi.org/10.1 029/2018TC005146

Blayney T, Najman Y, Dupont-Nivet G, Carter A, Millar I, Garzanti E, Sobel ER, Rittner M, Andò S, Guo Z, Vezzoli G (2016) Indentation of the Pamirs with respect to the northern margin of Tibet: Constraints from the Tarim basin sedimentary record. Tectonics 35(10):2345-2369. https://doi.org/10.1002/201 6TC004222

Bosboom R, Dupont-Nivet G, Grothe A, Brinkhuis H, Villa G, Mandic O, Stoica M, Huang W, Yang W, Guo Z, Krijgsman W (2014a) Linking Tarim Basin sea retreat (west China) and Asian aridification in the late Eocene. Basin Res 26(5):621-640. https://doi.org/10.1111/bre.12054

Bosboom R, Dupont-Nivet G, Grothe A, Brinkhuis H, Villa G, Mandic O, Stoica M, Kouwenhoven T, Huang W, Yang W, Guo Z (2014b) Timing, cause and impact of the late Eocene stepwise sea retreat from the Tarim Basin (west China). Palaeogeogr Palaeoclimatol Palaeoecol 403:101-118. https://doi.org/1 0.1016/j.palaeo.2014.03.035

Bosboom RE, Dupont-Nivet G, Houben AJP, Brinkhuis H, Villa G, Mandic O, Stoica M, Zachariasse WJ, Guo Z, Li C, Krijgsman W (2011) Late Eocene sea retreat from the Tarim Basin (west China) and concomitant Asian paleoenvironmental change. Palaeogeogr Palaeoclimatol Palaeoecol 299(3-4): 385-398. https://doi.org/10.1016/j.palaeo.2010.11.019

Bougeois L, Dupont-Nivet G, de Rafélis M, Tindall JC, Proust JN, Reichart GJ, de Nooijer L, Guo Z, Ormukov C (2018) Asian monsoons and aridification response to Paleogene sea retreat and Neogene westerly shielding indicated by seasonality in Paratethys oysters. Earth Planet Sci Lett 485:99-110. https:// doi.org/10.1016/j.epsl.2017.12.036

Burtman VS, Molnar P (1993) Geological and geophysical evidence for deep subduction beneath the Pamir. Spec Pap Geol Soc Am 281:1-76. https://doi. org/10.1130/SPE281-p1

Cao K, Wang GC, Bernet M, van der Beek P, Zhang KX (2015) Exhumation history of the West Kunlun Mountains, northwestern Tibet: evidence for a long-lived, rejuvenated orogen. Earth Planet Sci Lett 432:391-403. https://doi.org/10.101 6/j.epsl.2015.10.033

Cao K, Xu Y, Wang G, Zhang K, van der Beek P, Wang C, Jiang S, Bershaw J (2014) Neogene source-to-sink relations between the Pamir and Tarim Basin: insights from stratigraphy, detrital zircon geochronology, and whole-rock geochemistry. J Geol 122(4):433-454. https://doi.org/10.1086/676478

Chapman JB, Carrapa B, Ballato P, DeCelles PG, Worthington J, Oimahmadov I, Gadoev M, Ketcham R (2017) Intracontinental subduction beneath the Pamir Mountains: constraints from thermokinematic modeling of shortening in the Tajik fold-and-thrust belt. Bull Geol Soc Am 129:1450-1471. https://doi.org/1 $0.1130 / B 31730.1$

Chen X, Chen H, Lin X, Cheng X, Yang R, Ding W, Gong J, Wu L, Zhang F, Chen S, Zhang Y, Yan J (2018) Arcuate Pamir in the Paleogene? Insights from a review of stratigraphy and sedimentology of the basin fills in the foreland of NE Chinese Pamir, western Tarim Basin. Earth-Sci Rev 180:1-16. https://doi. org/10.1016/j.earscirev.2018.03.003

Clift PD, Zheng H, Carter A, Böning P, Jonell TN, Schorr H, Shan X, Pahnke K, Wei $X$, Rittenour T (2017) Controls on erosion in the western Tarim Basin: implications for the uplift of northwest Tibet and the Pamir. Geosphere 13(5): 1747-1765. https://doi.org/10.1130/GES01378.1

Cowgill E (2010) Cenozoic right-slip faulting along the eastern margin of the Pamir salient, northwestern China. GSA Bull 122(1-2):145-161. https://doi. org/10.1130/B26520.1

Decelles PG, Kapp P, Gehrels GE, Ding L (2014) Paleocene-Eocene foreland basin evolution in the Himalaya of southern Tibet and Nepal: implications for the age of initial India-Asia collision. Tectonics 33(5):824-849. https://doi.org/10.1 002/2014TC003522

Dupont-Nivet G, Krijgsman W, Langereis CG, Abels HA, Dai S, Fang X (2007) Tibetan plateau aridification linked to global cooling at the EoceneOligocene transition. Nature 445(7128):635-638. https://doi.org/10.1038/na ture05516
Feigl FJ, Fowler WB, Yip KL (1974) Oxygen vacancy model for the E1' center in SiO2. Solid State Commun 14(3):225-229. https://doi.org/10.1016/0038-1 098(74)90840-0

Heermance RV, Pearson J, Moe A, Liu L, Xu J, Chen J, Richter F, Garzione CN, Nie J, Bogue S (2018) Erg deposition and development of the ancestral Taklimakan Desert (western China) between 12.2 and 7.0 Ma. Geology 46(10): 919-922. https://doi.org/10.1130/G45085.1

Isozaki Y, Tada R, Sun Y, Zheng H, Toyoda S, Sugiura N, Karasuda A, Hasegawa H (2020) Origin of aeolian dust emitted from the Tarim Basin based on the ESR signal intensity and crystallinity index of quartz: the recycling system of fine detrital material within the basin. Geol Mag 157(5):707-718. https://doi.org/1 $0.1017 / 50016756820000242$

Jiang XD, Li ZX (2014) Seismic reflection data support episodic and simultaneous growth of the Tibetan Plateau since 25Myr. Nat Commun 5(1):1-7. https:// doi.org/10.1038/ncomms6453

Kapp P, DeCelles PG (2019) Mesozoic-Cenozoic geological evolution of the Himalayan-Tibetan orogen and working tectonic hypotheses. Am J Sci 319(3):159-254

Kaya MY, Dupont-Nivet G, Proust JN, Roperch P, Bougeois L, Meijer N, Frieling J, Fioroni C, Özkan Altıner S, Vardar E, Barbolini N, Stoica M, Aminov J, Mamtimin M, Zhaojie G (2019) Paleogene evolution and demise of the proto-Paratethys Sea in Central Asia (Tarim and Tajik basins): Role of intensified tectonic activity at ca. $41 \mathrm{Ma}$. Basin Res 31(3):461-486. https://doi. org/10.1111/bre.12330

Klug HP, Alexander LE (1974) X-ray diffraction procedure, 2nd edn. Wiley, Hoboken

Kutzbuch JE, Prell WL, Ruddiman WF (1993) Sensitivity of Eurasian climate to surface uplift of the Tibetan Plateau. Jour Geol 101(2):177-190. https://doi. org/10.1086/648215

Li X, Zhang R, Zhang Z, Yan Q (2018) What enhanced the aridity in Eocene Asian inland: global cooling or early Tibetan Plateau uplift? Palaeogeogr Palaeoclimatol Palaeoecol 510:6-14. https://doi.org/10.1016/j.palaeo.2017.10. 029

Li YP, Robinson AC, Gadoev M, Oimuhammadzoda I (2020) Was the Pamir salient built along a Late Paleozoic embayment on the southern Asian margin? Earth Planet Sci Lett 550:1-13. https://doi.org/10.1016/.j.epsl.2020.116554

Manabe S, Broccoli AJ (1990) Mountains and arid climates of middle latitudes. Science 247(4939):192-195. https://doi.org/10.1126/science.247.4939.192

Murata K, Norman M (1976) An index of crystallinity for quartz. Am J Sci 276(9): 1120-1130. https://doi.org/10.2475/ajs.276.9.1120

Nagashima K, Suzuki Y, Irino T, Nakagawa T, Tada R, Hara Y, Yamada K, Kurosaki Y (2016) Asian dust transport during the last century recorded in Lake Suigetsu sediments. Geophy Res Lett 43(6):2835-2842. https://doi.org/10.1002/201 5GL067589

Najman Y (2006) The detrital record of orogenesis: a review of approaches and techniques used in the Himalayan sedimentary basins. Earth-Sci Rev 74(1-2): 1-72. https://doi.org/10.1016/j.earscirev.2005.04.004

National Center for Atmospheric Research Staff (Eds). Last modified 20 Sep 2018. "The climate data guide: GPCC: Global Precipitation Climatology Centre."s

Negredo AM, Replumaz A, Villaseñor A, Guillot S (2007) Modeling the evolution of continental subduction processes in the Pamir-Hindu Kush region. Earth Planet Sci Lett 259(1-2):212-225. https://doi.org/10.1016/j.epsl.2007.04.043

Qiang X, An Z, Song Y, Chang H, Sun Y, Liu W, Ao H, Dong J, Fu C, Wu F, Lu F, Cai Y, Zhou W, Cao W, Xu X, Ai L (2011) New eolian red clay sequence on the western Chinese Loess Plateau linked to onset of Asian desertification about 25 Ma ago. Sci China Earth Sci. 54(1):136-144. https://doi.org/10.1007/ s11430-010-4126-5

Ramstein G, Fluteau F, Besse J, Joussaume S (1997) Effect of orogeny, plate motion and land-sea distribution on Eurasian climate change over the past 30 million years. Nature 386(6627):788-795. https://doi.org/10.1038/386788a0

Rittner M, Vermeesch P, Carter A, Bird A, Stevens T, Garzanti E, Andò S, Vezzoli G, Dutt R, Xu Z, Lu H (2016) The provenance of Taklamakan desert sand. Earth Planet Sci Lett 437:127-137. https://doi.org/10.1016/j.epsl.2015.12.036

Robinson AC, Ducea M, Lapen TJ (2012) Detrital zircon and isotopic constraints on the crustal architecture and tectonic evolution of the northeastern Pamir. Tectonics 31(2):1-16. https://doi.org/10.1029/2011TC003013

Robinson AC, Yin A, Manning CE, Harrison TM, Zhang SH, Wang XF (2007) Cenozoic evolution of the eastern Pamir: implications for strainaccommodation mechanisms at the western end of the Himalayan-Tibetan orogen. Bull Geol Soc Am 119(7-8):882-896. https://doi.org/10.1130/B25981.1 
Rutte D, Ratschbacher L, Khan J, Stübner K, Hacker BR, Stearns MA, Enkelmann E, Jonckheere R, PfänderGulzar JA, Sperner B, Tichomirowa M (2017) Building the Pamir-Tibetan Plateau—crustal stacking, extensional collapse, and lateral extrusion in the Central Pamir: 2. Timing and rates. Tectonics 36(3):342-384. https://doi.org/10.1002/2016TC004293

Saito K, Tada R, Zheng H, Irino T, Luo C, He M, Wang K, Suzuki Y (2017) ESR signal intensity of quartz in the fine-silt fraction of riverbed sediments from the yangtze river: a provenance tracer for suspended particulate matter. Prog Earth Planet Sci 4(1):4. https://doi.org/10.1186/s40645-017-0118-9

Smit MA, Ratschbacher L, Kooijman E, Stearns MA (2014) Early evolution of the Pamir deep crust from Lu-Hf and U-Pb geochronology and garnet thermometry. Geology 42(12):1047-1050. https://doi.org/10.1130/G35878.1

Sobel ER, Chen J, Schoenbohm LM, Thiede R, Stockli DF, Sudo M, Strecker MR (2013) Oceanic-style subduction controls late Cenozoic deformation of the Northern Pamir orogen. Earth Planet Sci Lett 363:204-218. https://doi.org/1 0.1016/j.epsl.2012.12.009

Sobel ER, Dumitru TA (1997) Thrusting and exhumation around the margins of the western Tarim basin during the India-Asia collision. J Geophys Res Solid Earth 102(B3):5043-5063. https://doi.org/10.1029/96JB03267

Sobel ER, Schoenbohm LM, Chen J, Thiede R, Stockli DF, Sudo M, Strecker MR (2011) Late Miocene-Pliocene deceleration of dextral slip between Pamir and Tarim: Implications for Pamir orogenesis. Earth Planet Sci Lett 304(3-4):369378

Stearns MA, Hacker BR, Ratschbacher L, Rutte D, Kylander-Clark ARC (2015) Titanite petrochronology of the Pamir gneiss domes: implications for middle to deep crust exhumation and titanite closure to $\mathrm{Pb}$ and $\mathrm{Zr}$ diffusion. Tectonics 34(4):784-802. https://doi.org/10.1002/2014TC003774

Sun D, Bloemendal J, Rea DK, Vandenberghe J, Jiang F, An Z, Su R (2002) Grainsize distribution function of polymodal sediments in hydraulic and aeolian environments, and numerical partitioning of the sedimentary components. Sediment Geol 152(3-4):263-277. https://doi.org/10.1016/S0037-0738(02 )00082-9

Sun D, Bloemendal J, Yi Z, Zhu Y, Wang X, Zhang Y, Li Z, Wang F, Han F, Zhang $Y$ (2011) Palaeomagnetic and palaeoenvironmental study of two parallel sections of late Cenozoic strata in the central Taklimakan Desert: implications for the desertification of the Tarim Basin. Palaeogeogr Palaeoclimatol Palaeoecol 300(1-4):1-10. https://doi.org/10.1016/j.palaeo.2010.11.015

Sun H, Liu X (2018) Impacts of the uplift of four mountain ranges on the arid climate and dust cycle of inland Asia. Palaeogeogr Palaeoclimatol Palaeoecol 505:167-179. https://doi.org/10.1016/j.palaeo.2018.05.040

Sun J, Liu W, Liu Z, Deng T, Windley BF, Fu B (2017) Extreme aridification since the beginning of the Pliocene in the Tarim Basin, western China. Palaeogeogr Palaeoclimatol Palaeoecol 485:189-200. https://doi.org/10.1016/ j.palaeo.2017.06.012

Sun J, Ni X, Bi S, Wu W, Ye J, Meng J, Windley BF (2014) Synchronous turnover of flora, fauna, and climate at the Eocene-Oligocene Boundary in Asia. Sci Rep 4(1):7463. https://doi.org/10.1038/srep07463

Sun J, Windley BF (2015) Onset of aridification by 34 Ma across the EoceneOligocene transition in Central Asia. Geology 43(11):1015-1018. https://doi. org/10.1130/G37165.1

Sun J, Ye J, Wu W, Ni X, Bi S, Zhang Z, Liu W, Meng J (2010) Late OligoceneMiocene Mid-latitude aridification and wind patterns in the Asian interior. Geology 38(6):515-518. https://doi.org/10.1130/G30776.1

Sun J, Zhang Z, Zhang L (2009) New evidence on the age of the Taklimakan Desert. Geology 37(2):159-162. https://doi.org/10.1130/G25338A.1

Tada R, Sato S, Irino T, Matsui H, Kennett JP (2000) 25. Millennial-scale compositional variations in late Quaternary sediments at site 1017, Southern California 1. In: Proc Ocean Drill Program, Sci Results, vol 167. https://doi. org/10.2973/odp.proc.sr.167.222.2000

Tada R, Zheng H, Sugiura N, Isozaki Y, Hasegawa H, Sun Y, Yang W, Wang K, Toyoda S (2010) Desertification and dust emission history of the Tarim Basin and its relation to the uplift of Northern Tibet. Geol Soc London, Spec Publ 342(1):45-65. https://doi.org/10.1144/SP342.5

Toyoda S (1992) Production and decay characteristics of paramagnetic defects in quartz: applications to ESR dating, Osaka University, Japan, Ph. D Thesis

Toyoda S, Hattori W (2000) Formation and decay of the E 1' center and of its precursor. Appl Radiat Isot 52(2):1351-1356. https://doi.org/10.1016/j.apra diso.2004.08.014

Toyoda S, Naruse T (2002) Eolian dust from the Asian deserts to the Japanese Islands since the last glacial maximum: the basis for the ESR method. Transactions 23:811-820
Uno I, Eguchi K, Yumimoto K, Takemura T, Shimizu A, Uematsu M, Liu Z, Wang Z, Hara Y, Sugimoto N (2009) Asian dust transported one full circuit around the globe. Nat Geosci 2(8):557-560. https://doi.org/10.1038/ngeo583

Wei X, Zheng H, Wang P, Tada R, Clift PD, Jourdan F, Luo C, Chen H (2018) Miocene volcaniclastic sequence within the Xiyu Formation from source to sink: implications for drainage development and tectonic evolution in Eastern Pamir, NW Tibetan Plateau. Tectonics 37(9):3261-3284. https://doi. org/10.1029/2018TC005008

Xu ZQ, He BZ, Zhang CL, Zhang JX, Wang ZM, Cai ZH (2013) Tectonic framework and crustal evolution of the Precambrian basement of the Tarim Block in NW China: new geochronological evidence from deep drilling samples. Precambrian Res 235:150-162. https://doi.org/10.1016/j.precamres.2013.06.001

Yin A, Rumelhart PE, Butler R, Cowgill E, Harrison TM, Foster DA, Ingersoll RV, Zhang Q, Zhou XQ, Wang XF, Hanson A, Raza A (2002) Tectonic history of the Altyn Tagh fault system in northern Tibet inferred from Cenozoic sedimentation. Bull Geol Soc Am 114(10):1257-1295. https://doi.org/10.1130/ 0016-7606(2002)114<1257:THOTAT>2.0.CO;2

Zheng H (2016) Asia dust production ramped up since Latest Oligocene driven by Tibetan Plateau uplift. Natl Sci Rev 3(3):271-274. https:/doi.org/10.1093/ nsr/nww040

Zheng H, Huang X, Butcher K (2006) Lithostratigraphy, petrography and facies analysis of the Late Cenozoic sediments in the foreland basin of the West Kunlun. Palaeogeogr Palaeoclimatol Palaeoecol 241(1):61-78. https://doi. org/10.1016/j.palaeo.2006.06.015

Zheng H, Tada R, Jia J, Lawrence C, Wang K (2010) Cenozoic sediments in the southern Tarim Basin: implications for the uplift of northern Tibet and evolution of the Taklimakan Desert. Geol Soc London, Spec Publ 342(1):6778. https://doi.org/10.1144/SP342.6

Zheng H, Wei X, Tada R, Clift PD, Wang B, Jourdan F, Wang P, He M (2015) Late Oligocene-early Miocene birth of the Taklimakan Desert. Proc Natl Acad Sci 112(41):E5558-E5559. https://doi.org/10.1073/pnas.1517735112

Zoura D, Hill DJ, Dolan AM, Hunter SJ, Tang Z, Haywood AM (2019) Atmospheric carbon dioxide, ice sheet and topographic constraints on palaeo moisture availability in Asia. Earth and Planet Sci Lett 519:12-27. https://doi.org/10.101 6/j.epsl.2019.04.035

\section{Publisher's Note}

Springer Nature remains neutral with regard to jurisdictional claims in published maps and institutional affiliations.

\section{Submit your manuscript to a SpringerOpen ${ }^{\circ}$ journal and benefit from:}

- Convenient online submission

- Rigorous peer review

- Open access: articles freely available online

High visibility within the field

- Retaining the copyright to your article

Submit your next manuscript at $>$ springeropen.com 